\title{
Decentralization of government and forestry in Indonesia
}

Paul Hasan Thung 

Working Paper 249

\section{Decentralization of government and forestry in Indonesia}

Paul Hasan Thung

Brunel University London 
Working Paper 249

(C) 2019 Center for International Forestry Research

(c) (i) Content in this publication is licensed under a Creative Commons Attribution 4.0 International (CC BY 4.0), http://creativecommons.org/licenses/by/4.0/

DOI: $10.17528 /$ cifor/007303

Thung PH. 2019. Decentralization of government and forestry in Indonesia. Working Paper 249. Bogor, Indonesia: CIFOR.

\section{CIFOR}

Jl. CIFOR, Situ Gede

Bogor Barat 16115

Indonesia

$\mathrm{T}+62(251) 8622-622$

$\mathrm{F}+62(251) 8622-100$

E cifor@cgiar.org

\section{cifor.org}

We would like to thank all funding partners who supported this research through their contributions to the CGIAR Fund. For a full list of the 'CGIAR Fund' funding partners please see: http://www.cgiar.org/our-funders/

Any views expressed in this publication are those of the authors. They do not necessarily represent the views of CIFOR, the editors, the authors' institutions, the financial sponsors or the reviewers. 


\section{Contents}

Acknowledgements $\quad$ iv

Executive summary $\quad$ v

1 Introduction 1

1.1 Note on language $\quad 2$

2 Aims and impacts 3

2.1 Democratization 3

2.2 Improved governance 3

2.3 Territorial stability 4

3 Dimensions 5

3.1 Administrative decentralization 5

3.2 Fiscal decentralization $\quad 6$

$\begin{array}{lll}3.3 \text { Political decentralization } & 6\end{array}$

4 Dynamics and issues $\quad 8$

4.1 Revision and recentralization $\quad 8$

$\begin{array}{lll}4.2 & \text { Identity politics } & 10\end{array}$

4.3 Formation of new districts and provinces (Pemekaran) 11

5 Decentralization of forestry $\quad 15$

$\begin{array}{lll}5.1 & \text { Forest governance decentralization } & 15\end{array}$

$\begin{array}{ll}5.2 \text { Forest Management Units } & 19\end{array}$

6 Conclusion 22

$\begin{array}{ll}\text { References } & 24\end{array}$

\section{List of figure}

1 Timeline of the various regulations granting (blue) and retracting (red) the authority to grant small-scale, short-term logging concessions to/from regency governments 1999-2002 (based on Dermawan et al. 2006). 


\section{Acknowledgements}

This working paper was written as a background study for CIFOR's research project titled "Understanding Migration and Remittances to Improve Forest Management Projects and Policies", with the financial support from the Federal Ministry for Economic Cooperation and Development, Germany. I would like to thank Bimbika Sijapati Basnett, Kartika Sari Juniwaty and Moira Moeliono for their support, input and feedback. 


\section{Executive summary}

The decentralization program that Indonesia embarked on in 1998 as part of widespread national reforms was unprecedented in scope and ambition. Although initially described in terms of a single, transformative event, over the last two decades it has unfolded in manifold, sometimes contradictory processes. The dynamics of decentralization continue today, even - or especially - in the remotest corners of the archipelago. Recent CIFOR research on the interface between human migration and forest management in Malinau, North Kalimantan showed the ongoing salience of legal reforms, the restructuring of local governments and innovations in forest governance. These decentralization processes give rise to hopes, aspirations and uncertainties that form the backdrop for decisions about both migration and land use.

This paper synthesizes previous analyses, overviews and evaluations of decentralization, supplemented with insights from more recent publications. A final section considers in more detail the decentralization of the forestry sector and the related introduction of Forest Management Units. The primary aim was to present a concise and up-to-date overview of the aims, dimensions and dynamics of decentralization, to support the analysis of CIFOR's fieldwork data from Malinau. This paper may furthermore be useful to anyone interested in processes of decentralization in Indonesia or elsewhere.

As described in Section 2, decentralization has had mixed success in achieving its three main aims. First, decentralization was intended to support the democratization of government by increasing people's awareness of, engagement with, and control over political issues. While the accountability and inclusiveness of district and village governments in regard to local people have improved overall, decentralization has also given rise to new, localized forms of marginalization and corruption. Second, decentralization was theorized to lead to improved governance and accelerated poverty allevation, by enhancing the quality and efficiency of service provision. However, current evidence suggests that the impact of decentralization on regional development has been minimal, that decentralized service delivery is relatively inefficient and that regional inequalities in service delivery have increased as a result. Third, decentralization was a response to widespread dissatisfaction with centralized rule, especially in resource-rich regions such as Aceh, Riau, Papua and East Kalimantan. By empowering regencies and districts, providing material benefits to local elites, and creating the conditions for the flourishing of local (rather than regional) identities, decentralization successfully appeased and diverted regional separatist movements.

To understand how decentralization works, three different dimensions are distinguished: administrative, fiscal and political decentralization. Administrative decentralization refers to the transfer of powers and responsibilities from the central to lower levels of government. Fiscal decentralization is the transfer of control over fiscal resources from the central to lower levels of government. Political decentralization is about making political processes more accountable to local constituents rather than to central government, for example by increasing the decision-making power of subnational representatives and instituting direct elections of local councils and executives. Each of these three dimensions of decentralization involves a complex set of rules and structures, the outlines of which are described in Section 3.

Equally important as the aims and design of decentralization, are the unintended dynamics and issues described in Section 4. First of all, decentralization has been subject to repeated revisions. Some of these may be seen as responses to flaws in the design or excesses in the effects of decentralization. But revisions are also the product of intra-governmental disagreements and conflicts of interest, for example between different levels or departments of government. The contested nature of decentralization has given rise to unclear and contradictory regulations, which present both 
opportunities and challenges for the different actors trying to advance their interests. Second, the cessation of efforts to suppress local identities in combination with electoral reforms that created the need for local leaders to appeal to local identities, reinforced a resurgence of identity politics. Ethnicity, religion and locality became increasingly important in local politics, and traditional institutions underwent a revival. Third, decentralization has given rise to an intense but controversial proliferation of new provinces, regencies and districts, a phenomenon called 'pemekaran' (flowering).

The reforms since 1998 have increased opportunities and formal support for subnational actors to control forests. This decentralization of the forestry sector in Indonesia devolved powers over forestry and redistributed a greater share of the benefits from forestry to regional governments. Indonesia's new program of Forest Management Units (FMUs), which were supposed to render forest management more responsive to local social and ecological contexts, can also be seen as part of the project of decentralization. The dynamics and issues related to the decentralization of the forestry sector are discussed in Section 5.

The conclusion highlights a number of themes that merit further investigation. These include the impacts of the most recent (2014) revision of the central legal framework of decentralization; the cumulative effects of decentralization processes on identities and aspirations; and the interplay between decentralization and the regulation of plantation agriculture, mining and forest fires. 


\section{Introduction}

Moves towards decentralization of government have previously been initiated at various times for the Indonesian archipelago (Wollenberg et al. 2009; 7-10; Booth 2014), but new laws passed in 1999 and their coming into force in 2001 were so resolute and ambitious that 2001 has been dubbed the "Big Bang" of decentralization (Hofman and Kaiser 2004). The central government adopted this policy in response to political, economic and environmental crises, drawing on the transnational decentralization policy narratives of the time (McCarthy 2005). Indonesia was expected to rapidly transform "from one of the most centralized systems in the world to one of the most decentralized ones" (Hofman and Kaiser 2004, 16).

However, system change is a complex, uneven and contested process, such that "a social scientist attempting to understand how decentralization is affecting a specific local context is likely to come across a muddled and rather chaotic state of affairs that hardly seems to resemble the scenario described in the decentralization policy narratives" (McCarthy 2004, 1199). This brief aims to provide tools for analyzing this state of affairs in Indonesia by disentangling some of the main aims, mechanisms, dynamics and issues.

This review is mainly based on existing analyses, overviews and evaluations found through Google Scholar and by tracing the references from those publications. Occasionally, this is supplemented with a primary reading of relevant laws and regulations. By drawing together a range of different perspectives and approaches, this paper provides a map towards a comprehensive understanding (Lund et al. 2018) of decentralization that transcends disciplinary boundaries.

The next two sections introduce the basics of decentralization. Section 2, titled Aims and impacts, elaborates on the three principal motivations for decentralization: democratization, improved governance and territorial stability. The urgency of each of these three issues in Indonesia around 1998 formed the impetus for highly ambitious decentralization policies. Taking a broad view of these goals, the currently existing evidence on the extent to which decentralization has achieved these original goals is briefly assessed.

Section 3 goes into technical detail on how decentralization works. Following the World Bank Institute and Marco Bünte (Litvack and Seddon 2000; Bünte 2003), there are three dimensions of decentralization: administrative (concerning executive powers and public service delivery), fiscal (concerning financial flows between parts of government) and political (concerning legislative powers, electoral systems, accountability). The section outlines how each dimension is designed in Indonesia's recent decentralization laws.

Section 4 looks at more contested and unplanned dynamics of decentralization, to show how it has created "new conditions of possibility" (Long 2017, 118) and the ways in which people have engaged with them. The opportunities of decentralization have been enthusiastically taken up by some, sometimes even going beyond the program afforded by the decentralization laws. Others, however, have pushed back against decentralization, delaying and sometimes reversing its implementation. More than that, the possibilities afforded by decentralization have spun off into unforeseen dynamics with vast implications, such as the increasing salience of cultural and place-based identities and the splitting of regions into independent administrative units.

Section 5, focuses on the decentralization of a specific sector: forestry. Forests in Indonesia have often been de facto managed and controlled by local authorities and communities, even where this is neither acknowledged nor stimulated by official national policy. However, as described in Section 
5.1 the reforms since 1998 increased opportunities and formal support for subnational actors to control forests and fostered new forms of local forest governance. This decentralization of the forestry sector in Indonesia fits in with an international trend towards the decentralization of natural resource management (Larson 2005). Section 5.2 goes on to discuss an interesting project in forest governance in Indonesia of establishing Forest Management Units (FMUs), which were supposed to "encourage implementation of true decentralization" by rendering forest management more responsive to local social and ecological contexts (Hasan, in Kartodihardjo et al. 2011, iii). Indonesian social forestry policies might also be considered a form of forest decentralization, insofar as they devolve power over forests to subnational entities, in this case, local communities (Wollenberg et al. 2009). These are not discussed here since they are not part of the broader program of government decentralization, but excellent assessments can be found elsewhere (Moeliono et al. 2017; Myers et al. 2017; Fisher et al. 2018).

\subsection{Note on language}

In the following, 'central government' (pemerintah pusat) indicates the Jakarta-based national level of government, which includes the president, the national parliament and the various ministries. 'Regional government' (pemerintah daerah) comprises both 'provincial' (provinsi) and 'regency' (kabupaten) or 'municipal' (kota) governments. Regencies and municipalities are made up of 'districts' (kecamatan), which (in the case of regencies) in turn contain multiple 'villages' (desa). Some publications translate kabupaten as "district" and kecamatan as "subdistrict". Where such sources are cited, "district" is replaced with "[regency]". 


\section{Aims and impacts}

\subsection{Democratization}

Decentralization from 1998 was part of wider national reforms, following the large popular demand for democratization that had contributed to the fall of President Suharto. This so-called era of reform saw a freeing of the press and political parties, electoral reforms and a reduction in the political role of the military (Aspinall and Fealy 2003, 2-3). Devolving power to lower levels of government fitted with a global trend towards decentralization among post-authoritarian states, and was supposed to further democratization, because people are (theoretically) more aware of and engaged with political issues in their more immediate environment (Aspinall and Fealy 2003, 4). Empowering local governments was furthermore expected to encourage renewed political engagement after many years of New Order 'antipolitics', which had "depriv[ed] ordinary citizens and prospective leaders alike of critical knowledge about how to engage in politics" (Antlöv 2003a, 75).

Electoral reforms are considered to have increased the accountability and inclusiveness of district and village governments to local communities, especially through the establishment of direct elections for subnational executive positions and an increase in the powers of subnational people's assemblies (Tomsa 2015; Antlöv et al. 2016). In many cases "candidates with the support of some political parties and grassroots support groups were more successful than traditional local elites with a dubious background [and] local leaders who failed to deliver were often not re-elected as a punishment"(Ziegenhain 2017, 65). The agency of local actors in previously marginalized areas has grown significantly and they are actively and inventively reshaping power relations (Haug et al. 2017c). In this sense, "decentralization has played a role in dispersing political power across political levels and geographic areas, thereby inhibiting the extreme concentration of power that characterized Soeharto's New Order government" (Ostwald et al. 2016, 140).

The emerging processes of "demarginalization", however, are accompanied by new, localized forms of marginalization (Haug et al. 2017a, 40). There are also ongoing concerns regarding "decentralization of corruption," (Schulte Nordholt and van Klinken 2007a, 18) i.e. the reproduction and multiplication on the local level of forms of corruption that were formerly concentrated in the center (Ziegenhain 2017, 70), such as the pervasiveness of money politics (both vote buying and having to pay political parties for nomination in local elections), and the creation of local political dynasties by families (Malley 2003; Tomsa 2015).

\subsection{Improved governance}

Another aim of decentralization is to improve governance through "greater allocative efficiency" (Litvack and Seddon 2000, 10). ${ }^{1}$ Because decentralization brings government closer to the people, accountability and responsiveness to specific local needs would, theoretically, increase (Malley 2003). Additionally, theory dictates that decentralization would lead to interdistrict competition for human and financial resources, which would "lift general governance quality" (Hill 2014, 3). All this would improve the provision of services, spur socioeconomic development and lift living standards (Hill 2014). 
However, evidence for achieving these goals is lacking. National statistics show that the impact of decentralization on subnational development has been 'minimal' and that regional development dynamics have been characterized by remarkable continuity before and after decentralization (Hill and Vidyattama 2016). While service delivery has improved according to popular perception, economic data do not provide evidence for a positive effect of decentralization on actual service delivery (Ostwald et al. 2016). According to socioeconomic indicators of health, education and infrastructure, decentralization brought about increased interregional inequalities in service delivery as local capacity for making use of new opportunities varied (Holzhacker et al. 2016; Leer 2016). The uneven outcomes of decentralization moreover depend on levels of elite capture and local accountability, reflecting the relative power of local elites and civil society (McCarthy 2005). Much depends on the quality of local leadership (von Luebke 2009). Overall, subnational governments in Indonesia have so far proven to be inefficient service providers, which according to Lewis (2014) has to do with spending relatively much on personnel and administration and too little on actual service delivery. Local corruption also appears to be an important obstacle to the improvement of service delivery (Aspinall 2014; Lewis 2017).

Additionally, Lewis speculates that subnational governments may have little incentive to improve service delivery because of "insufficient citizen demand for higher service quality" (Lewis 2014, 150), as suggested by high rates of self-reported citizen satisfaction with service delivery in contexts where "objective evidence" (Lewis 2014, 152) reveals a need for improvement.

\subsection{Territorial stability}

Decentralization was also a response to a fear of secession of various regions in light of views held by a number of separatist movements. Around 1998, dissatisfaction with centralized, authoritarian rule was widespread. The level of dissatisfaction was evidenced by the actions of regional separatist movements that had long been suppressed becoming more vocal, reflecting long-standing armed conflicts such as in Aceh and East Timor; and by opinions coming from resource-rich regions (such as Aceh, Riau, Papua, East Kalimantan) about not receiving a fair share from the wealth created from resource-based activities on their lands (Wollenberg et al. 2009; Fadliya and McLeod 2010). In addition, there was widespread and growing local opposition to the undemocratic, "pseudo-electoral process" (Malley 2003, 107) through which the central government put favored regional politicians in executive positions (Hofman and Kaiser 2004; Booth 2014). The fact that decentralization initially empowered regencies and districts much more than provinces strategically undermined separatist sentiments, which were strongest at the provincial level (Aspinall and Fealy 2003; Hofman and Kaiser 2004; Bräuchler 2015).

Decentralization is considered to have been successful in preventing further secessions from Indonesia, although it may be noted that scholars had questioned the likelihood of the actual breaking up of Indonesia from the start (Aspinall 2010; Mietzner 2014). To explain how decentralization appeased separatist sentiments, Mietzner points out that decentralization has benefited both local elites and the broader population, the former through material benefits, the latter in the form of opportunities for political participation, and a flourishing of local identities, local media and NGOs (Mietzner 2014). Decentralization channeled the discontent that fueled separatist movements away from regioncenter relations, as "local political elites and activists immediately shifted from protesting about the depredations of the central government to organizing to capture political power at the local level" (Aspinall 2010 26). 


\section{Dimensions}

\subsection{Administrative decentralization}

One central dimension of decentralization is the transfer of powers and responsibilities from the central to lower levels of government. ${ }^{2}$ The central government remained completely in charge of 'absolute government affairs,' namely security and defense, foreign affairs, fiscal and monetary affairs, development planning, religion, justice and the police (Hofman and Kaiser 2004; Ardiansyah and Jotzo 2013). But there was devolution of administrative authority and service delivery concerning "concurrent government affairs" (Urusan Pemerintahan Konkuren), which included health, education, housing, agriculture, natural resource management, infrastructure and more (Hofman and Kaiser 2004; Sutiyo and Maharjan 2017, Table 3.1). ${ }^{3}{ }^{4}$ Consequently, while in 1999 almost $90 \%$ of civil servants had been employees of the central government, in 2002 this was less than $25 \%$ (Rohdewold 2003). ${ }^{5}$ In the 2014 law on regional government, policy-making authority over concurrent government affairs is divided as follows. The central government sets national "norms, standards, procedures and criteria", ${ }^{6}$ and the regional government has the right to set regional policies, so long as these policies are guided by the instructions of the central government. ${ }^{7}$ Devolution is limited by the principles of "accountability, efficiency and externality" (akuntabilitas, efisiensi, dan eksternalitas). ${ }^{8}$ This means that concurrent government affairs will in principle fall under the authority of the district/ city government, unless these affairs are located in multiple districts/cities, or impact on multiple districts, or are used by people from multiple districts, or are more efficiently managed on a higher level. In those cases, they fall under the authority of the provincial government or, following the same principles, authority may be moved up even further to the central government. Moreover, the central government can claim authority on any affairs that are in the "national strategic interest" (Rahmatunnisa 2015, 513). ${ }^{9}$ This division of responsibilities over different levels of government varies on a case-by-case basis (Sutiyo and Maharjan 2017, Table 3.1) and changes over time (Rudy et al. 2017). The 2014 revision, ${ }^{10}$ for example, is seen to (partly) recentralize power, among other things by moving control over natural resources from the district level to the provincial level (Myers et al. 2016; Sahide et al. 2016b). Section 5.1 examines these arrangements and their dynamics in more detail for forestry.

\footnotetext{
2 Set out in in UU 22/1999, later revised by UU 32/2004, and revised again by UU 23/2014

3 UU 22/1999 Article 11; UU 23/2014 Article 12

4 These tasks are performed either directly by the center, or, following the principle of 'deconcentration', by local "vertical institutions", which represent and are under direct command of the central government. (UU 22/1999 Article 7; UU 23/2014 Article 10)
}

5 Although this reorganization sounds impactful, Ryaas Rasyid, the Minister of Regional Autonomy at that time, later wrote: "The reallocation of about two million central government officials who have been working at various central agencies in the provinces, regencies, and municipalities [...] was not so difficult to manage [...] because basically there were no physical movements involved. The officials remained in their existing jobs, working in the same place and offices. Only the status of their offices was changed from central representatives to regional or local agencies" (Rasyid 2004, 70)

6 UU 23/2014 Article 16

7 UU 23/2014 Article 17

8 UU 23/2014 Article $13 \S 1$

9 This was a new provision of the 2014 law, which had been absent in the 2004 and 1999 laws.

10 UU 23/2014 


\subsection{Fiscal decentralization}

In accordance with the principle of 'money follows function,' the fiscal resources available to local governments were greatly increased under decentralization (Sutiyo and Maharjan 2017). ${ }^{11}$ Between 2000 and 2002, fiscal transfers from the central to the subnational governments as a percentage of domestic revenue almost doubled, from 16.0\% (IDR 32.9 trillion) to $31 . \%$ (IDR 94.5 trillion) (Rohdewold 2003). Fiscal transfers to regencies and cities as a proportion of central government expenditure rose from 24\% in 2001 to $30 \%$ in 2008 (Booth 2011). By 2012, about half of national government expenditure was at subnational levels (Lewis 2014). Although subnational governments attained some authority for raising their own revenues from taxes and levies (Pendapatan Asli Daerah, PAD) and subnational loans (Pinjaman Daerah), ${ }^{12}$ they rely on fiscal transfers from the central government for over $80 \%$ of their budgets (Ardiansyah and Jotzo 2013). ${ }^{13}$ These transfers (collectively called the "Balancing Fund" or Dana Perimbangan), consist of a "General Allocation Fund" (Dana Alokasi Umum, DAU), a "Specific Allocation Fund" (Dana Alokasi Khusus, DAK) and a "Revenue Sharing Fund" (Dana Bagi Hasil, DHB).

The DAU is the largest component fiscally, accounting for over two-thirds of fiscal transfers, and covers general expenditures needed to execute the devolved government functions. The central government is required to transfer at least $26 \%$ of its net domestic revenues to the DAU (Fadliya and McLeod 2010). The DAU replaced a system of discrete subsidies used to pay civil servant salaries and ministerial and presidential grants used to cover specific expenditures on deconcentrated tasks (Fadliya and McLeod 2010). The DHB derives from taxes and income from natural resource management, the revenues of which are shared in varying proportions. Central government in general retains $80 \%$ of personal income tax, almost $85 \%$ of oil revenues and almost $70 \%$ of natural gas revenues, ${ }^{14}$ but shares most revenues from property taxes, forestry and mining with the subnational levels of government in the areas from which these revenues come. The exact ways in which these shared revenues are allocated to source districts and provinces are various and complex (Fadliya and McLeod 2010). While the subnational levels of government can decide themselves how to use the DAU and DHB, the DAK consists of earmarked subsidies for specific projects in the national interest (cf. Colongon 2003).

Despite the formal autonomy over a large part of the budget, the considerable reliance by regions on transfers from the center rather than own-source revenues (PAD), limits de facto regional autonomy, since it gives the central government "considerable leverage" over subnational governments (Booth 2011, 49, 53). Since 2001, there has been a "significant and steady increase in both the size and scope of DAK funding" (Fadliya and McLeod 2010,; Booth, 2011, 47), reflecting a tendency towards recentralization as discussed in Section 4.1

\subsection{Political decentralization}

Political decentralization makes subnational political processes more accountable to their constituents rather than to the central government, for example, by increasing the decision-making power of subnational representatives and instituting direct elections of local councils and executives (Litvack and Seddon 2000; Bünte 2003; Ziegenhain 2017). Decentralization in Indonesia changed the relation between central and local governments from a relationship of command to one of coordination.

\footnotetext{
11 Set out in UU 25/1999, Revised by UU 33/2004, ...

12 But in 2016 it was reported that none of Indonesia's subnational governments had floated any bonds because of limitations in Indonesia's financial market (Nasution 2016).
}

13 Own-source revenues (PAD), however, are relatively more important for provincial governments, which in 2013 obtained 50\% of their total revenues from PAD, compared with $11 \%$ for district governments (Nasution 2016).

14 Papua and Aceh, however, receive much larger shares of oil and gas revenues due to their special autonomy status (Schulte Nordholt and Klinken 2007a,; Nasution 2016). 
Whereas previously the local government was accountable primarily to the central government, now, ideally, "local government leaders are politically accountable only to the people through local councils" (Sutiyo and Maharjan 2017, 30). Law 22/1999 separated the powers of the executive and legislative branches of government, giving the directly elected local legislative assemblies (DPR-D) oversight over the local budget, the power to appoint the executives (governors, district heads and mayors - who were previously appointed by the center) and the power to impeach them (Antlöv 2003b; Schulte Nordholt and van Klinken 2007a; Skoufias et al. 2011). ${ }^{15}$

Correspondingly, the village was "no longer under the authority of the subdistrict, but [...] an autonomous level of government" (Antlöv 2003b, 197). A village council (Badan Perwakilan Desa, BPD) now replaced the village representative assembly (Lembaga Musyawarah Desa, LMD), as a mechanism by which the village people could for the first time hold their village governments to account. The BPD, unlike the earlier LMD, was not appointed by the village head but directly elected by the villagers. The BPD was granted "the power to draft village legislation, to approve the village budget, and to monitor village government" (Antlöv 2003b, 199). The village head, who unlike the higher-level local government heads had been and would continue to be elected directly by the people, was now accountable to the BPD rather than to the subdistrict head. ${ }^{16}$

These political arrangements have remained controversial and subject to change. For example, the structure outlined above was deemed to grant excessive power to the legislative assemblies and was adjusted in 2004. ${ }^{17}$ At the provincial and district levels, it introduced direct elections for governors (executive heads of provinces), district heads and mayors, and they could no longer be dismissed by local parliaments (Schulte Nordholt and van Klinken 2007a; Erb and Sulistiyanto 2009). At the village level, the village representative board was transformed into a 'village consultative board', the members of which were now to be "appointed through consensus rather than elected" (Antlöv et al. 2016, 168) and which could only give advice, without decision-making power. These changes, according to Antlöv, disempowered the BPD, which was "a result of lobbying by the association of village heads, which had argued that BPDs were creating conflicts and paralysing village governments" (Antlöv et al. 2016, 167). This reduced the capacity for villagers to keep the village head accountable in between elections, although the head was still directly elected - now in 6-year terms. The 2014 revision is said to further strengthen the position of the governor and president and to re-emphasize the hierarchical relationship between central and regional governments (Jaweng 2014; Myers et al. 2016). Political dynamics such as these will be explored in more detail in Section 4.

15 It may be noted that the distinction between administrative and political decentralization used in this paper, which is based on the World Bank Institute and Bünte (Litvack and Seddon 2000; Bünte 2003), is different from how Agrawal and Ribot (Agrawal and Ribot 1999; Ribot 2002) conceptualize these terms. Agarwal and Ribot equate administrative decentralization with 'deconcentration', which transfers responsibilities to lower administrative levels which remain accountable upwards to the central government. They contrast their concept of administrative decentralization with a concept of political, or 'democratic' decentralization, as the devolution of power to lower levels of government that are accountable downward to the people in their jurisdiction. In this framework, administrative and political decentralization are mutually exclusive types, respectively a "weak" and a "strong" form of decentralization (Ribot 2002, ii-iii). The Indonesian decentralization laws, however, clearly demarcate decentralization from 'deconcentration' (UU 22/1999 Article $1 \mathrm{~d}-\mathrm{e}$ ) by indicating that the former implies regional autonomy and the latter does not. The way administrative and political decentralization are conceptualized in this paper, as referring to two separate dimensions of decentralization that can be separately assessed in one and the same program of decentralization, gives them greater analytical purchase. It may, in fairness, also be noted that Agrawal and Ribot's framework provides similar analytical possibilities by distinguishing between dimensions of power and accountability.

16 This restructuring of village governance applies only to villages (desa), which are located in districts (kecamatan), and not to urban communities (kelurahan), which are located in cities (kota), as explained in Antlöv (2003)

17 UU 32/2004 


\section{Dynamics and issues}

\subsection{Revision and recentralization}

Considering the high stakes of decentralization, it is unsurprising that its implementation has been subject to political contestation. The "unclearness and vagueness" (Bräuchler 2015, 61) of the early regulations on decentralization left ample space for political interests to influence implementation. Within the bureaucracy, local and central government actors have looked to influence the new distribution of powers and resources in their favor.

Parts of central government have from the start been reluctant to assist in the implementation of these laws which would reduce their own powers (Hofman and Kaiser 2004). The Ministries of Forestry, of Home Affairs and the National Land Agency have moved from an initial "passive refusal to implement certain policies" to an "active opposition to key features of the decentralisation package" (Tomsa 2015, 162). This was compounded by the fact that parliamentary elections and a change in presidency took place within a couple of months after the passing of the decentralization laws. ${ }^{18}$ While the programmatic decentralization laws of 1999 were drafted in a spirit of radical reform, the governments that formulated the implementing legislations had "less sympathy for the full autonomy allowed by the [1999 decentralization] laws" (Wollenberg et al. 2009, 14). Since an important motivation for the central Indonesian Government to decentralize was to appease anti-center sentiments, arguments for recentralization gained in force when the position of the central government was more secure (Simarmata and Firdaus 2016). This is sometimes referred to as "the pendulum effect" (Warman 2016, 40), following the metaphor of a pendulum that continually swings back and forth from decentralization to recentralization over the course of history.

On the other hand, the local politicians and elites that directly benefit from decentralization pushed for stronger devolution. They found support from national and international NGOs, many academics and large sections of the general public. Dissatisfied with the slow and limited progress on legal implementation, subnational actors soon seized upon the possibilities afforded by the 1999 laws by claiming authority over important assets such as oil fields and harbors (Bünte 2004).

Despite this de facto enacting of decentralization by local authorities, legally there have been many moves towards recentralization since 1999 (Resosudarmo 2004). Important parts of the broad and farreaching changes outlined in the 1999 decentralization laws were postponed, excluded or toned down in the implementing regulations (Bünte 2004; Dermawan et al. 2006; Fadliya and McLeod 2010). ${ }^{19}$ The 2004 revision ${ }^{20}$ of the decentralization laws, for example, was "seen as an attempt by the central government to regain some of the authority and functions that had been devolved to local governments under Laws 22/1999 and 25/1999" (Soesastro and Atje 2005, 30). The revision defined the provincial governor as a representative of the central government and gave them responsibility for guiding and supervising local governments, whereas previously the provincial government had had "virtually no authority over local governments" (Soesastro and Atje 2005, 30). ${ }^{21}$ The 2014 revision ${ }^{22}$ further moved powers away from the regency to the provincial and national levels, importantly in areas of natural

18 On top of that, within two years, the new president, Abdurrahman Wahid, was impeached by parliament and replaced by

Megawati Sukarnoputri.

19 PP 25/2000

20 UU 32/2004 and UU 33/2004

21 UU 32/2004 Articles 37-38

22 UU 23/2014 
resource management such as forestry, mining, fisheries and marine resources (Steni 2016). It stressed the hierarchical relationship between central and regional governments, strengthened the position of the governor and introduced administrative penalties for regency governments if they acted against the national interest (Jaweng 2014). The 2014 revision is therefore said to "complete the process of [re] centralization that had begun with UU 32/2004" (Simarmata and Firdaus 2016, 7). ${ }^{23}$

Although bureaucratic politics are an important driver of recentralization, they are also a response to the abuse of new powers at the lower levels. Whether such abuse of new powers is a sufficient reason for recentralization, or a poor excuse for the self-interested grabbing back of power by actors in central government, is a matter of some debate (Simarmata and Firdaus 2016). In any case, moving authority over natural resource management back to the provincial level was framed as a response to the unsustainable exploitation of natural resources by the regency governments, which is discussed in relation to forestry in Section 5.

Laws and regulations after 1999 have not merely recentralized power. Not only do they actually further decentralization in some areas, they also address important issues that are primarily technical or managerial rather than political. The 2004 revision, for example, dealt with imbalances in the system of fiscal transfers; clarified the position of provincial government, which had remained vague in the 1999 laws (Bennett 2010); saw the introduction of direct elections for governors, district heads and mayors ${ }^{24}$; and increased some tax and natural resources revenue sharing (DHB) entitlements for subnational governments (Soesastro and Atje 2005). A 2009 law on minerals and coal mining gave regions authority to issue mining permits, except for oil and gas (Resosudarmo et al. 2014). ${ }^{25}$ The 2014 law clarified the management of civil servants, local capacity building and the organization of public service delivery, including complaint mechanisms (Rahmatunnisa 2015).

Another problem addressed by newer decentralization laws was the excessive use of regulatory powers. Extending law-making power to local governments (as per Law 22/1999) led to a proliferation of regional regulations (by-laws) which increase the "bulk, complexity and uncertainty" of Indonesia's legal system and "have been criticised for being misdirected or unclear, violating citizens' rights, imposing excessive taxes, even breaching Indonesia's international obligations" (Butt 2010, 1) ${ }^{26}$ A new law ${ }^{27}$ that was intended to curb excessive taxation was largely unsuccessful (Butt and Parsons 2012). The 2014 law therefore included a more detailed regulation of the creation and monitoring of by-laws (Rahmatunnisa 2015). ${ }^{28}$

Actors outside the central government can also effectively apply pressure to further decentralization and to limit recentralization. Outside actors, for example, enabled the new village law in $2014,{ }^{29}$ which increased the powers and resources available to the village government. Although this new law was arguably against the interests of central government, it was pushed for by a collaboration of policy communities: village heads, national civil society organizations, international donor institutions and

\footnotetext{
23 "[...] penyempurna proses sentralisasi yang sudah dimulai sejak UU No. 32/2004"

24 UU 32/2004 Article 24

25 UU 4/2009 - provinces could issue permits for operations that are located or impact upon more than one district, districts could issue permits for operations within the district (articles 6-8)

26 Butt found, moreover, that the bureaucratic and judicial review system that was supposed to serve as a check on the lawmaking authority of local governments, is flawed because it only challenges those local laws that impose illegal tax or other charges, while upholding or leaving unchallenged other bad laws (Butt 2010).

27 UU28/2009

28 UU 23/2014 Articles 236-257

29 UU 6/2014
} 
foreign governments (Vel et al. 2017).$^{30}$ The limited power of the central government to recentralize is exemplified by the short life of another 2014 law $^{31}$ which abolished direct elections for governors, district heads and mayors. The public outrage that followed compelled the government to revoke the new law only four months after it passed through parliament (Tomsa 2015). The new village laws also contained some recentralizing aspects. Village budgets, for example, were now allocated directly by the central government, without interference by provincial or regency governments (Myers et al. 2016).

In spite of recentralizing tendencies, it has still been maintained that Indonesia became, within two decades, "one of the most decentralized states of the world" (Ziegenhain 2017, 59).

\subsection{Identity politics}

Decentralization, especially in its early years, reinforced a resurgence of local identity politics (Aspinall and Fealy 2003; Schulte Nordholt and van Klinken 2007b). In part, this resulted from the cessation of efforts to suppress local identities and enforce a Javanese cultural hegemony (Mietzner 2014). Additionally, electoral reforms created the need for district and village leaders to appeal to specific local identities in order to be elected (Vel 2008; Mietzner 2014).

This has stirred discourses about ethnicity. Across Sumatra, for example, there was a rise in interest in transnational Malay culture and identity. Decentralization had given local elites the authority to kindle economic relations with Malaysia and Singapore independent of approval from Jakarta and were "capitalizing on their shared Malayness to attract investment" from Malaysia and Singapore (Sakai 2009, 63). At the national level, by contrast, it may be argued that the political role of ethnicity started declining after the first years of decentralization. Aspinall pointed out that the leaders of the democratic transition "made the consequential decision to require all parties that wished to contest legislative elections to demonstrate that they had a broad nationwide presence", effectively preventing regionalist and ethnic parties from participating in national politics (Aspinall 2011, 296). The fact that most power was devolved to district rather than to provincial levels, although aimed at undermining secessionist movements, also had the effect of fragmenting ethnic identities: it "did not remove ethnicity from politics, but it did undercut its ability to play a significant role in national politics" (Aspinall 2011, 306).

Decentralization laws have actively promoted the revitalization of local traditional institutions, or 'adat', such as in Law 32 of 2004 which stipulated that villages should be governed in accordance with their local traditions (Mietzner 2014; Bräuchler 2015). Additionally, authority over religious affairs devolved to the district level has fostered Islamization, as many districts issued religious policies that favored the local Muslim majority (Crouch 2009; Robinson 2011). Similar things happened in districts with a Christian or Hindu majority. In many cases, partisan religious policies are unconstitutional, as they offend the equality of religious beliefs (Ziegenhain 2017). These different dimensions of identity (locality, ethnicity, tradition, religion) are connected and often conflated.

The process of drafting and implementing the 1999 laws coincided with post-1998 incidents of violence between ethnic groups, such as between (trans-)migrants and indigenous people in Kalimantan and Maluku (van Klinken 2007; Bräuchler 2015). It is important to note that most of the post-1998 incidents of communal violence in fact started before the decentralization laws were passed and ended before they were implemented in 2001, and since then, large-scale violence has "largely

30 However, these policy communities "have been less successful in securing implementation of the new law, as this process is still dominated by the government bureaucracies that were 'defeated' in the law-making process" (Vel et al. 2017, 447).

31 UU 22/2014 
dissipated" (Mietzner 2014, 53-54). "Decentralization", as Bräuchler pointed out, "was not the cause for the recent violence, which instead had its main roots in the structural injustices and marginalization policies of the Suharto era and its legacies, such as the poor performance of the security forces and the absence of an effective judicial system" (Bräuchler 2015, 39).

Nevertheless, decentralization did in the beginning create an atmosphere of uncertainty and anxiety in which local elites positioned themselves to compete for control over devolved powers and resources (Ziegenhain 2017). In addition, the legal promotion of adat has "the potential to enforce social dividing lines in heterogeneous village communities", which can increase the likelihood of violence (Bräuchler 2015, 50). But decentralization and the revitalization of adat also create opportunities for inclusion and integration (cf. Duncan 2007). In the Moluccan Archipelago (Maluku), adat "became both a means to organize the conflict as well as a means to restore peace," as local adat leaders have played a leading role in reconciliation efforts (Bräuchler 2015, 119). Meanwhile, the revitalization of traditional village institutions made the position of Butonese immigrant minorities in Maluku's West Seram District more precarious at the village level. However, decentralization simultaneously enabled them to start participating in regional politics with remarkable success (Bräuchler 2017). One conclusion reached is that, overall, "decentralisation has been (among other factors) responsible for a strong reduction of ethnically motivated violence in recent years", because it has made available political opportunities for local elites to pursue wealth and power "without having to resort to violence" (Ziegenhain 2017, 67).

\subsection{Formation of new districts and provinces (Pemekaran)}

Decentralization has been accompanied by the splitting up of administrative units to create many new provinces, regencies, districts and villages (henceforth 'regions'), a phenomenon called pemekaran or "regional proliferation". ${ }^{32}$ Pemekaran was not entirely new. Many new provinces were created in the 1950s. Although no provinces were split during Suharto's presidency (1966-1998), there was a small increase in numbers of regencies and a large increase in numbers of villages (Booth 2011). Pre-1999 pemekaran, however, was initiated by the center. Since 1999, the possibilities and incentives for regions to initiate the creation of a new administrative unit have increased. The 1999 decentralization law contained instructions for a forthcoming government regulation to regulate the creation of new regions. ${ }^{33}$ This government regulation was issued the following year and clarified the goals of redrawing territorial boundaries: "a. to improve service delivery to the community; $b$. to accelerate the growth of democratic life; c. to accelerate regional economic development; $\mathrm{d}$. to accelerate the management of regional potential; e. to improve security and order; f. to improve harmonious relationships between centre and regions." ${ }^{34}$ The regulation further described some of the conditions for pemekaran regarding economic capacity, regional potential, sociocultural and sociopolitical factors, population size, area size and 'other considerations ${ }^{35}$. 'Other considerations ${ }^{6}$ included a requirement that new provinces should consist of at least three regencies and/or cities, and new regencies or cities should consist of at least three districts. ${ }^{36}$

The subsequent intensity with which new regions were being proposed and formed was not intended or planned for (Schulte Nordholt and van Klinken 2007a). Eight new provinces had been created by 2015 (Bräuchler 2015) and the number of districts and municipalities increased from 292 in 1998 to almost

\footnotetext{
32 Literally "flowering".

33 UU 22/1999 Article 5

34 PP 129/2000 Article 2: “[...] a. peningkatan pelayanan kepada masyarakat; b. percepatan pertumbuhan kehidupan demokrasi; c. percepatan pelaksanaan pembangunan perekonomian daerah; d. percepatan pengelolaan potensi daerah; e. peningkatan keamanan dan ketertiban; f. peningkatan hubungan yang serasi antara Pusat dan Daerah"

35 PP 129/2000 Article 3

36 PP 129/2000 Article 10
} 
500 in 2009 (Bunnell 2009). Pemekaran has been especially influential in Kalimantan (expanding from 29 districts in 1996 to 53 districts in 2007), Sulawesi (from 40 to 69) and Papua/Maluku (from 18 to 45) (McWilliam 2011).

According to some, pemekaran is "largely driven from below" (Schulte Nordholt and van Klinken 2007a, 19). Indeed there are good reasons for local actors to push for the splitting of regions.

Proponents often talk about administrative efficiency, which is said to follow upon bringing local government closer to the people and creating smaller jurisdictions (Fitrani et al. 2005; Aspinall 2013), but that formulation belies the political and economic interests at play (Kimura 2007). It is probably more accurate to speak of a "desire [for] a greater degree of unmediated access to the national centre, which in many regards represents a powerful and desirable resource" (Long 2017, 122, 125; cf. Schulte Nordholt and van Klinken 2007a). This desire relates to a condition of "marginality in the periphery" (Kimura 2007, 72), "in which a population feels held back by the actions of their regional government and thus at a disadvantage in terms of infrastructure, economic opportunities, services and skills, compared to other members of the same district, regency or province" (Long 2017, 122). Such arguments align well with the central state's official goal of improving service delivery, democracy, development, security and harmonious relations between central and regional government (e.g. Eilenberg 2017).

Pemekaran processes also articulate a local sense of identity. A common justification for redrawing borders is to create "regional units that are more homogeneous in terms of ethnicity, language, religion, urban-rural character or even income level" (Fitrani et al. 2005, 66). The new region could, in other words, "provide an administrative home for a local ethnic or sub-ethnic group that lives in a concentrated area and to ameliorate tension with other groups" (Aspinall 2013, 39; cf. Duncan 2007). Although such justifications have in part been mobilized by local elites with hidden agendas, the importance of identity cannot be reduced to this legitimizing function. This can be seen from the fact that issues of identity sometimes obstruct rather than facilitate pemekaran (Roth 2007), and from evidence showing that newly created regencies "are indeed more ethnically homogenous and even experience less political violence" (Pierskalla 2016, 250). Identities are often rooted in complex histories of migration and contestation. In North Maluku, disputes between different groups of villagers over the redrawing of district borders in 1999 escalated into violent conflicts. Although peace was restored in 2001, one group of villages went on to mobilize 'socio-territorial concepts' related to ancient sultanates to contest their inclusion in the 'wrong' regency after North Maluku split into four different regencies in 2003 (Jäger 2017). The meanings of identities are also subject to continuous reinvention. Movements promoting ethnic Malayness have led to the establishment of the new province of the Riau Archipelago, a 'province for Malays'. The social and political challenges that giving shape to this 'province for Malays' gave rise to, have in turn led Riau Islanders to develop new understandings of Malayness (Long 2013).

Despite the claims of local elites that pemekaran serves the interests of the entire region, it is well established that they have used pemekaran for advancing personal goals (e.g. Vel 2008). 'Aspiring" elites aim to obtain positions of power in the new region's administration (Kimura 2007), as do "ethnic leaders looking for new political units they can rule when their terms expire" (Aragon 2007, 60). Opportunities for rent-seeking were augmented by the increased fiscal resources flowing to subnational governments and new possibilities were created for raising own revenue from taxes and natural resource exploitation. Each new region could expect a small construction boom, as it required a range of new government buildings at the center, "filling the pockets of those who control contract bids" (Kimura 2007, 90). The creation of a new administration comes with "new opportunities to appoint family or friends to civil service positions" (Aspinall 2013, 39).

Local drivers, however, are not enough to explain the proliferation of regions, which still require approval from national-level government. Because of the involvement of political actors at different levels, pemekaran is not simply driven 'from below', but by "multilevel alliances across different 
territorial administrative levels", or "territorial coalitions" (Kimura 2010, 415; cf. Pierskalla 2016). Personal politics play a role here. The creation of the Province of Gorontalo, formerly part of North Sulawesi, was strongly supported by President Habibie, who had family roots there, and by General Wiranto, whose wife came from the region (Kimura 2007). Then there were straightforward financial benefits. National parliament members received bribes from local elites wanting to get national permission for establishing a new district (Kimura 2007; Tomsa 2015). Established political parties moreover sold their party affiliation and support to regional candidates in elections for the newly opened representative positions (Bennett 2010). There were also national electoral benefits to be obtained from supporting proliferation, since the democratization of electoral laws had organized electoral districts along provincial lines (Kimura 2010). There is even speculation about a long-term strategy to increase the number of provinces outside Java and Bali, as this could lead to an increase in national parliament seats for parties with strong backing outside Java and Bali, and might stifle competition by making it more difficult for new parties to fulfil the legal requirement of maintaining offices in at least one-third of all provinces (Kimura 2007). ${ }^{37}$ The splitting of the Province of Irian Jaya into three separate provinces in 2003 was different again, because it was enforced by a controversial presidential decree in an attempt to reduce secessionism (McGibbon 2004; Booth 2011). ${ }^{38}$

Pemekaran was controversial from the start. It put a financial burden on the central government because, on top of the cost of new government buildings, creating smaller districts tends to increase the per capita cost of government staff wages (Hofman and Kaiser 2004). Moreover, the process could 'dilute' the government's capacity and authority, such that sometimes new positions remained vacant and the new governments struggled to become operational (McWilliam 2011). There are also concerns that regional proliferation may increase deforestation, by creating new incentives and possibilities for local bureaucrats and politicians to allow legal and illegal logging (Myers et al. 2016). Combining satellite data on deforestation in Indonesia between 2001 and 2008 with data on administrative splits, it has been calculated that "subdividing a province by adding one more district increases the overall deforestation rate in that province by $8.2 \%$ " (Burgess et al. 2012, 1709).

Further, there has been debate about whether pemekaran reduces poverty or increases inequality. An early evaluation of the impact of pemekaran on regional inequality found mixed results, but calculated that an increase in the numbers of regencies and municipalities within a province was correlated to an increase of interregional inequality in the Human Development Index (HDI) (Brata 2008). These increases are ascribed to a regional "aspiration for inequality," which was said to in many cases drive pemekaran: "the richer part of the region, believing that the backward part was holding it back, decided to go it alone - [...] the better off parts registering an increase in HDI while the worse experience decreases" (BPS et al. 2004, 10, 58). In contrast, a more recent evaluation of the impact of pemekaran on poverty reduction in regencies found that: "Mean and median household per capita consumption in the [regencies] that split grew 50-65 per cent faster than in the districts that did not, and increases in net enrolment [in primary education] were twice as high" (Ilmma and Wai-Poi 2014, 125). Moreover: "[regencies] that have split enjoy 9-12 per cent faster poverty reduction than those that have not" (Ilmma and Wai-Poi 2014, 127). ${ }^{39}$

Other studies emphasize the creation of intraregional forms of marginalization. The creation of the Regency of Kutai Barat in East Kalimantan in 2008 turned the previously marginalized Dayak into a ruling majority, led to investments in local infrastructure and brought much wealth to the new regency.

37 Despite these many reasons for actors to support the creation of new regions, the process is always contested and difficult and proposals often fail. The mother region may be unwilling to give up control, elected representatives may be reluctant to run for new elections, different factions may disagree over the details, there may not be enough funds to bribe parliamentarians with, or a change of rules my undermine the plans, to name a few possible complications (Quinn 2003; Kimura 2007; Roth 2007; Vel 2007; Eilenberg 2017).

38 Inpres No. 1/2003

39 Thus refuting Tommy Firman's $(2013,193)$ hypothesis that "[l]ocal government splits do not seem to reduce the poverty level, induce economic growth and improve the quality of public service provision in the new [sic] established regions [...]". 
However, inequalities between and within villages increased, as the process of creating a new regional center also created new peripheries and accelerated environmental degradation. Haug soberingly concluded that: "only a small number of people prosper while a large proportion of the population in Kutai Barat remains empty-handed" (Haug 2017, 253). A review of what happened on the Mentawai Islands of West Sumatra after attaining regency status in 1999 is even more damning. As in Kutai Barat, new peripheries emerged in the form of ethnic discrimination and the exclusion of people living in remote areas. But that author especially deplores "how easily the new political elite is able to let go of their former ideals and rhetoric" (Eindhoven 2007, 88) Instead of nature conservation and indigenous self-determination, she finds "omnipresent corruption and money politics," which leads her to conclude that "opportunistic behaviour on the part of the local elite, losing all interest in the wellbeing of the communities on whose image of indigeneity they have been preying for decades, is the rule rather than the exception" (Eindhoven 2007, 87, 89).

In an attempt to slow down the creation of new districts and provinces, the 2004 revision of decentralization therefore introduced stricter requirements for the establishment of new administrative units, including a minimum of five subdistricts (kecamatan) for the establishment of a district (kabupaten) and a minimum age ${ }^{40}$ for a region before splitting is allowed (Eilenberg 2017). ${ }^{41}$ These rules were evidently not restrictive enough for President Yudhoyono, who in 2009 found reason to declare a moratorium on the creation of new districts and provinces, although this was never consolidated in an official regulation. The national parliament in 2012 decided that the moratorium was over and "resumed approving the creation of new administrative entities, including the new province of North Kalimantan" (Tomsa 2015, 166-167). Following critical evaluations of the performance of new regions commissioned by the Yudhoyono government, the 2014 law on regional government introduced further regulations of pemekaran, including the requirement that "an aspiring new region [...] undergo a three- to five-year preparation period during which it will be evaluated by the central government" and after which the president could now decide to reject the creation of the region (Tomsa 2015, 167). ${ }^{42}$ 


\section{Decentralization of forestry}

\subsection{Forest governance decentralization}

\subsubsection{Distribution of authority over forest between central and regency governments}

As part of the broader decentralization reforms, the decentralization of forestry was expected to render forest management more efficient, equitable and democratic (Larson 2005; Barr et al. 2006a). The official rationale was to increase local participation and restore the rights of those who had historically been unjustly excluded from natural resources. This was also expected to enhance rural development and alleviate poverty. In practice, other reasons for the state to decentralize forest management were often seen to be more important, such as cutting costs, improving conditions for private investment and increasing state legitimacy; in addition, pressure was exerted by international donors (Larson 2005). In Indonesia, the International Monetary Fund's structural readjustment programs required a reduction of the costs of government service delivery, which provided an important impetus for the decentralization of forestry (Barr et al. 2006a). Paradoxically, such decentralization programs can increase centralized control over forests, by assigning management responsibilities to lower levels and imposing bureaucratic procedures without devolving significant decision-making power (Larson 2005).

When it comes to forest governance, the main redistribution of power that the decentralization reforms of 1999 established was between the Ministry of Forestry and the forestry services at the regency level (DINAS Kehutanan Kabupaten). As a result of the 1999 laws, "the [regency] forest departments became part of the [regency] government, answerable to the head of the [regency] (the bupati), rather than a division of the central Ministry of Forestry" (Burgess et al. 2012, 1716). District governments thus gained the power to issue small-scale logging concessions and forest conversion permits, to monitor and regulate the activities of small- and large-scale concession holders, to impose taxes on forest products, to propose areas for forest conversion to the central Ministry of Forestry, to monitor the implementation of forest conversion and to patrol forests to check for illegal activity (McCarthy 2005). Some concluded that the regency forestry services were "the main point of control over much of the forest estate" (Burgess et al. 2012, 1716).

That conclusion, however, is debatable. Some of the most important powers over forests have remained centralized throughout the recent wave of decentralization. Others argue, therefore, for example, that "[e]ven in the brief period of the 'high season of regional autonomy' between 1999 and 2002, forestry was much more centralized in Indonesia than at any time prior to independence, with a centralized bureaucracy having far-reaching powers across the archipelago" (Warman 2016, 39). The Ministry of Forestry maintained the power to assign and change forest classifications (such as "protection forest", "limited production forest" or "conversion forest"), even if in some cases the regent's signature is required to approve the plans (Myers et al. 2016). The Ministry of Forestry also retained the power to issue licenses for most commercial activities within forest areas, and to set criteria and standards for a broad range of forest management activities (Resosudarmo 2004; Resosudarmo et al. 2014).

In practice, this distribution of power has often been unclear, uncertain and/or contested. This is in large part the effect of a "legal tug-of-war over authority for forestry in Indonesia" (Dermawan et al. 2006, 7), significantly between the Ministry of Forestry and regency governments (Barr et al. 2006b). The Ministry of Forestry has frequently pushed back against the implementation of decentralization and acted as a force for recentralization, "something of an institutional counterweight to the Ministry 
of Regional Autonomy"43 (Barr et al. 2006a, 2). The rest of this section shows how this power struggle is manifested. Section 5.1.2. examine a much-studied episode in the decentralization of forest governance in Indonesia - during the period referred to in the previous paragraph as 'the high season of regional autonomy' - in which regency governments were briefly granted the authority to issue logging permits. Section 5.1.3 discusses how this struggle has led to a situation where many actors are confused about the distribution of power, where insecurities incentivize unsustainable forest management, and where contestation about forest maps persist.

Amid all this volatility and controversy, the fiscal decentralization of revenues from forest exploitation remained remarkably uncontroversial and stable. The 1999 decentralization laws ${ }^{44}$ stipulated that regional governments would, as part of the revenue sharing funds (DHB, see Section 3.2), retain $80 \%$ of revenues from the forestry sector within their province/district (previously $45 \%$ ). Regional governments would furthermore, as part of their special allocation funds (DAK), gain control over $40 \%$ of reforestation funds (previously $0 \%)^{45}$ (Resosudarmo 2004; Barr et al. 2006a). This benefit sharing arrangement was upheld in the 2004 revision of fiscal decentralization ${ }^{46}$ and, it seems, has been ever since.

\subsubsection{The granting and revoking of the power to issue logging concessions}

As part of the 1999 push for decentralization, a governmental regulation ${ }^{47}$ and an implementing regulation of the Ministry of Forestry $(\mathrm{MoF})^{48}$ awarded regency governments the authority to issue short-term (1-year), small-scale ( $<100 \mathrm{ha})$ logging permits in production and conversion forests (Resosudarmo 2004). The MoF postponed this right in early $2000,{ }^{49}$ but reestablished it later that year. ${ }^{50}$ In 2002, the MoF revoked ${ }^{51}$ its 2000 decree, and later that year the central government took back almost all authority over logging concessions by governmental regulation. ${ }^{52}$ Following this latest regulation, regency governments could issue permits only for very low rates of timber harvest (Dermawan et al. 2006). Figure 1 presents a timeline of these different regulations.

This short-lived decentralization of authority over logging concessions was fraught with problems and unforeseen consequences. The most-cited problem was that regency governments started handing out many more concessions than was deemed desirable and with little regard for environmental conditions (Resosudarmo 2003; Dermawan et al. 2006). Apparently, regency elites prioritized short-term gain over long-term sustainability (Moeliono et al. 2009). In part, this may also have been a result of overdrawn expectations that regional autonomy would require regional governments to become more self-supporting in terms of revenues (Barr et al. 2006a).

Another issue was that the large number of concessions being allocated exceeded the monitoring capacities of the regencies, which, combined with the influx of "tractors, trucks, and bulldozers" from Malaysia triggered by the increased logging activity, also created an increase in illegal logging (Barr

43 The establishment of the Ministry of Regional Autonomy in November 1999 was contested by the Ministry of Home Affairs, the Ministry of Forestry, the Ministry of Mining and the army. The Ministry of Regional Autonomy was abolished in August 2000 and decentralization has since been led by the Directorate General of Regional Autonomy as part of the Ministry of Home Affairs (Hofman and Kaiser 2004; Smith 2008).

44 UU 25/1999 Article 6.2

45 UU 25/1999 Article 8.4

46 UU 33/2004 Article 14

47 PP 6/1999

48 Kemenhut 310/1999 to 317/199

49 Kemenhut 084/2000

50 Kemenhut 05.1//KPTS-II/2000

51 Kemenhut 541/2002

52 PP 34/2002 


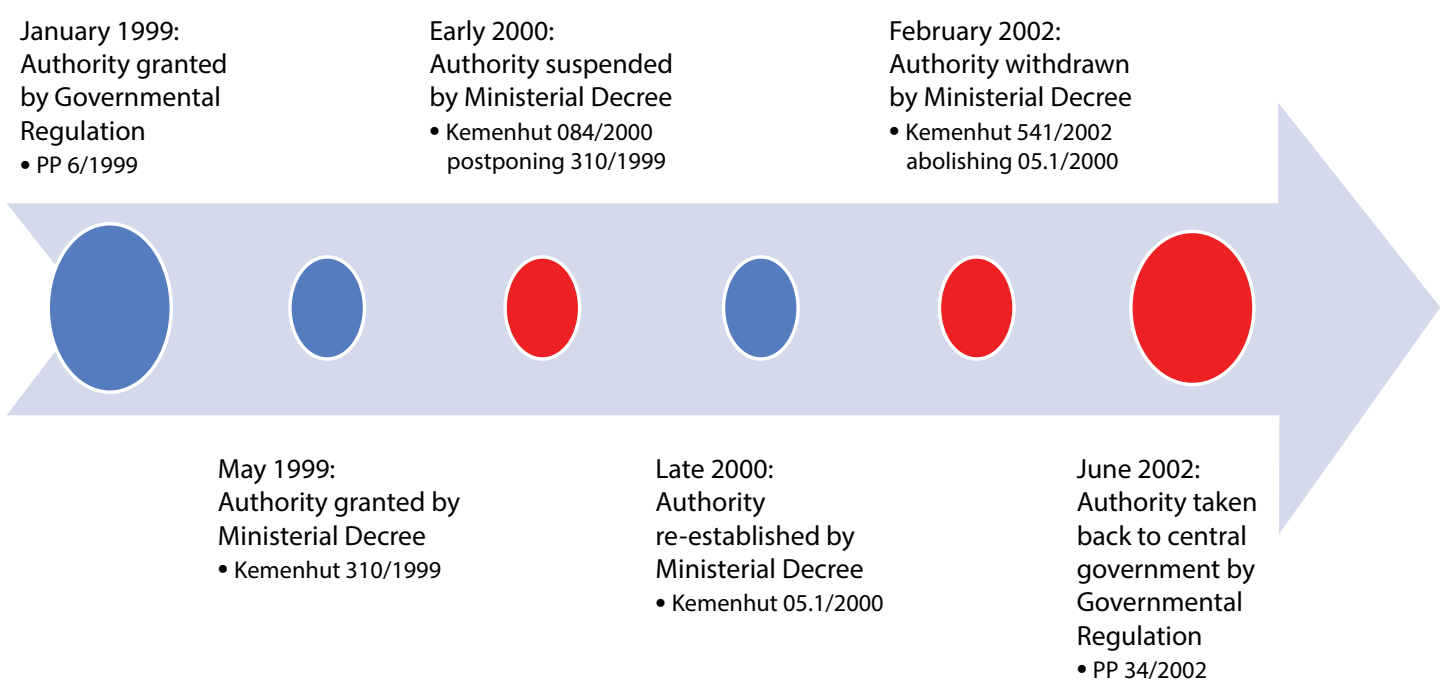

Figure 1. Timeline of the various regulations granting (blue) and retracting (red) the authority to grant small-scale, short-term logging concessions to/from regency governments 1999-2002 (based on Dermawan et al. 2006).

et al. 2006b, 127; see also Casson and Obidzinski 2002). Additionally, the spike in logging activities, combined with a less repressive political climate, triggered sometimes violent conflicts between local communities and logging companies, as well as intercommunity conflicts (McCarthy 2005; Palmer and Engel 2007; Yasmi et al. 2009; Bräuchler 2017). Furthermore, hopes that the decentralization of authority over small-scale concessions would enable local communities to obtain greater access to forest resources were not fulfilled. The high technical and financial demands of managing a concession meant that communities still needed to rely on outside companies (Dermawan et al. 2006).

The story of rampant deforestation caused by regency governments with too much authority has become a rhetorical instrument that legitimizes "a systematic effort by the MoF to reconsolidate the central government's authority in the forestry sector" (Barr et al. 2006a, 14). The MoF argued that the problems outlined above showed that regencies were not yet capable of assuming authority over forest management, and therefore issued regulations to recentralize authority. These measures were framed as a postponing of decentralization: legal authority would be redistributed to the district governments "gradually and selectively", according to "institutional capacity, vision and mission". ${ }^{53}$ Such promises, however, were seen as empty gestures, especially since they were not followed up (Dermawan et al. 2006). Although their legal right to issue small-scale logging permits was retracted, several regencies continued to issue such permits for some years (Dermawan et al. 2006).

Many scholars object to the central government's arguments that the lack of capacity and unsustainable forest governance practices at the regency level justify the recentralization of control. They argue that, first, if the central government is serious about decentralization, it should take responsibility for raising the capacity of regional governments. And second, if forest governance was unsustainable in the early 2000 s, that was a result of highly dynamic and uncertain circumstances as well as flawed design and poor implementation, rather than an inherent feature of decentralized forest management. It is noted, furthermore, that the logging and forest conversion permits that regency governments issued in the 3 years before their powers were curtailed covered a relatively small area ("at most a few hundred thousand hectares"), and that there is little evidence to suggest that the concessions issued since then by the Ministry of Forestry are managed more sustainably (Barr et al. 2006b, 128). By recentralizing forest management, these scholars argue, the government is missing an opportunity to benefit from 
decentralized forest management and to exploit the local capacities that had already started to develop (Barr et al. 2006b; Dermawan et al. 2006; Arnold 2008; Moeliono et al. 2009; Bullinger and Haug 2012).

Some commentators have concluded that " $[\mathrm{t}]$ he short period of 'big bang' decentralisation in the forestry sector thus came to an end by legal means in 2002" (Bullinger and Haug 2012, 247). However, the neat and bounded image of an "era of forestry sector decentralization" that has "effectively ended" (Dermawan et al. 2006, 1) belies the complexities and continuities of decentralization and its implications for forestry. As discussed in Section 5.1.3, debates about and shifts in the distribution of authority over forests across levels of government are not limited to the power to issue logging concessions and did not end in 2002.

\subsubsection{Legal ambiguity, insecurity and contestation}

When it comes to the decentralization of administrative power over forests, the division of powers over forests between different levels of government is often unclear, leaving many actors confused (Simarmata and Firdaus 2016). Legal ambiguity arises from inconsistencies within (see Resosudarmo 2003) and between different laws and regulations. For example, the decentralization laws classified natural resource management as a concurrent government affair (see Section 3.1) and hence implied that district governments would gain authority over forest management. The 1999 Forestry Law ${ }^{54}$ and the implementing 2002 Government Regulation, on the contrary, in significant ways restricted the authority of regional governments over forests. The latter indefinitely delayed the transfer of power to regional government by making it conditional on regional governments' institutional capacity, vision and mission (Dermawan et al. 2006; Grumblies 2017) ${ }^{55}$ Such ambiguity is made worse by a lack of clear hierarchy between different legal instruments, and a lack of institutional mechanism for resolving inconsistencies between them (Barr et al. 2006b). Moreover, there has been little public participation in policy-making and not enough resources have been made available to support public interest litigation through which the public can hold government to account (Arnold 2008).

These legal inconsistences can be attributed to a "lack of legal-regulatory coordination among government agencies" (Barr et al. 2006b, 123) or "legislatively entrenched departmentalism" (Arnold 2008 , 96). National laws are not drafted in a process of collaboration between different ministries, but tend to be drafted by a single ministry and reflect the political interests and preferences of that ministry. Different groups can consequently appeal to those legal instruments that best suit their own interests (Resosudarmo 2004).

The powers of the regency government relating to forests also remain highly insecure. The decentralization of powers has no constitutional backing and could theoretically be revoked at any moment (Arnold 2008). This has indeed happened at various times. The power to issue logging concessions is but one example. The 2014 law has taken back many more powers over forests from the regency governments and moved them to the provincial governments. Following this law, regencies have lost the authority to engage in forest planning, to form a forestry service and to issue local regulations related to forestry. The only forest authority that remains for regencies/cities is the management of Taman Hutan Raya (Tahura), small forest parks in or near cities, for conservation, research, education and recreation ${ }^{56}$ (Simarmata and Firdaus 2016). The resulting condition of "legaladministrative volatility" (Sloan et al. 2018, 298) is thought to generate incentives for the rapid and unsustainable exploitation of natural resources (McCarthy 2005; Moeliono et al. 2009).

54 UU 41/1999; PP 34/2002

55 PP $34 / 2002$

56 UU 23/2014 BB. Pembagian Urusan Pemerintahan Bidang Kehutunan, p.116 
Finally, there is contestation over which areas are properly part of Indonesia's forest estate (kawasan hutan). Although the Ministry of Forestry has extensive authority over official forest lands, it has little to say over non-forest lands. However, the different levels of government cannot agree on a single map that indicates the boundaries of the forest estate. Their continued use of different maps is a cause of conflict and hampers the implementation of other spatial planning and development policies (Resosudarmo et al. 2014). The goal of arriving at one map of the forest estate that can count on broad support from different levels of government and society, is one of the objectives set for a new policy initiative that introduces a system of Forest Management Units, as will be discussed in Section 5.2.

\subsection{Forest Management Units}

\subsubsection{Concept}

Another important, ongoing reform in Indonesian forest governance is the introduction of Forest Management Units (FMUs) ${ }^{57}$ An FMU is "a public service provider, a permanent management entity and an operational unit of a manageable and controllable size of forest under the responsibility of national and subnational governments" (FORCLIME 2015, 3). As this definition reflects, the FMUs are about: (1) the introduction of locally based, professional and publicly accountable forest management organizations, (2) the legal demarcation of designated, permanent forest areas and (3) the definition of territorial units appropriate for efficient management by such a body.

While the principal motivation behind this reform appears to be the reduction of deforestation and forest degradation, the idea of FMUs recognizes that a range of issues must be addressed to reach that aim. A programmatic paper outlining the concept of FMUs specified three root causes of deforestation and forest degradation in Indonesia, which the implementation of FMUs was hoped to resolve, namely (1) the competing claims of the state and local communities on the ownership or use rights of forest areas, (2) the weakness of forestry institutions at the local level and (3) the lack of valuation of the environmental services of forests in planning processes (Kartodihardjo et al. 2011).

FMUs, as public service providers, are expected to take on forest management tasks, which include creating and implementing short- and long-term management plans in accordance with administratively designated functions, upholding forest laws and creating inventories of forest resources. FMUs are directly responsible for these tasks in state forests, unless management has been handed over to third parties such as private concession holders or local communities. In the latter cases, the FMUs are supposed to monitor and evaluate those parties' planning processes and managing activities, and to give advice. FMUs can also attract their own sources of investment and establish their own income, by selling forest products or environmental services, such as through a planned international system of payments for mitigating forest-related carbon emissions called REDD+ (Kartodihardjo et al. 2011; Kim et al. 2016).

Three additional features of FMUs stand out. First, FMUs are intended to be responsive to the variable and dynamic conditions at the local level (Kartodihardjo et al. 2011). FMUs could implement government forest policies in locally appropriate ways, and give input and feedback to the policy makers. They could function as "policy intermediaries", who "make sense of policies and regulations from different levels of governments, manage ambiguity, negotiate, bargain and exercise discretion to implement them in local contexts" (Kim et al. 2016, 72). Following theories of adaptive governance, this requires: "(1) building knowledge of ecosystem dynamics; (2) allowing constant learning to underpin adaptive management; (3) supporting flexible institutions and polycentrism; and (4) developing capacity for dealing with the unpredictable" (Riggs et al. 2018, 3).

57 The equivalent in Indonesian is KPH, short for Kesatuan Pengelolaan Hutan. 
Second, as an intermediary, an FMU can resolve conflicts and facilitate collaboration between the multiple levels of government, the private sector and local community stakeholders (Kim et al. 2016). An important intended outcome of this mediation is to establish and secure forest boundaries. In line with this function, FMUs are "the first government entity managing natural resources with a legal mandate to communicate and work with indigenous people and local communities", as stipulated in PP 6/2007 (Fisher et al. 2017, 9). FMU leaders indeed reported that they saw conflict mediation as one of their most important tasks (Fisher et al. 2017). For this reason, Riggs et al. call the FMU a "bridging organization", which "can support management institutions to work with one another so that they can build consensus on how their landscapes might deliver the optimal range of societal benefits" (Riggs et al. 2018, 3).

Third, the territorial demarcation of FMUs is supposed to follow the boundaries of ecosystems, rather than to follow the administrative division of functions assigned to parts of ecosystems. In other words, an FMU should constitute "a forest ecosystem unit in a cohesive natural landscape with a reasonable span of managerial control, without concern for the different forest functions" (Kartodihardjo et al. 2011, 10). In line with the landscape approach to forest management (Sayer et al. 2013), FMUs can cross administrative boundaries and contain multiple types of uses. As such, FMUs are supposed to help manage the synergies and trade-offs between different social, economic and ecological goals and achieve "harmonisation of forest utilisation by various parties" (Kartodihardjo et al. 2011, 10).

Although sometimes framed as such, it is not entirely obvious that FMUs are a tool for decentralization. The concept of FMUs aligns with the goals of decentralization insofar as they are supposed to bring the government closer to the people and enable a more equitable distribution of benefits. FMUs should manage forests in locally appropriate ways by recruiting and training staff from local communities. However, they do not quite devolve power over forests to these communities, since their tasks are mostly limited to the day-to-day management and the implementation of policy. Whether or not FMUs contribute to a decentralization of power relating to forests, then depends on how they are positioned within the state bureaucracy, which has shifted over the course of their development (Bae et al. 2014; Sahide et al. 2016b).

\subsubsection{Development}

The concept of FMUs can be traced to the Basic Forestry Law of 1967 (UU 5/1967) and the consensus, back then, about "the need to provide boundaries for forest areas to be preserved as permanent forest" as "an absolute prerequisite for sustainable forest management" (Kartodihardjo et al. 2011, 3). The predecessors of FMUs were developed, in other words, in response to the need to consolidate forest boundaries in order to support sustained timber production. The demarcation of forest units served as the basis for granting forest use concessions to logging operations, and came to function as units for forest planning as well. This took place mainly in production forests on Java. With the revised Forest Law of 1999 (UU 41/1999), the regulatory framework for these so-called Production Forest Concession Units was expanded to also apply to nonproduction forest areas such as protected forests (Hutan Lindung), conservation forests (Hutan Konservasi) and national parks (Taman Nasional). The legal mandate to establish FMUs outside production areas and outside Java, however, was neglected in practice until 2007 (Hasan 2011; Kartodihardjo et al. 2011). The concept of FMUs was reintroduce' by a new regulation on forest planning in 2007 (PP 6/2007) (Ngakan et al. 2008), ${ }^{58}$ and the establishment of FMUs accelerated from 2010 with support from the German Government (Riggs et al. 2018). This support was delivered in large part by the German Society for International Cooperation (GIZ) through the bilateral Forests and Climate Change (FORCLIME) program led by the Indonesian Ministry of Forestry (Sahide et al. 2016a).

58 For more details, see the Ministry of Forestry's collection of relevant legal articles between 1999 and 2011 (MoF 2011). 
Although the concept of FMUs developed out of earlier regulatory frameworks applied to production forests on the island of Java, the strong role of the German Government is said to have left a stamp on the contemporary design of FMUs (Sahide et al. 2016a), which adopts principles from Germany's tradition of forest management: "manageable sizes of units, sound professional formation and permanent training of all FMU personnel, the presence of FMU staff in the forest area (resort-based management), and a functioning monitoring system" (FORCLIME 2015, 3).

As of April 2014, 120 FMUs had been established, of which 20 were operational (FORCLIME 2015). By June 2015, 130 FMUs were officially operational (Fisher et al. 2017). The Indonesian Government in its Medium-Term Development Plans for 2015-2019 planned to have established 629 FMUs by 2019, covering all of its official forest lands (Bappenas 2015). Reportedly, the Ministry of Environment and Forestry provided significant financial support for this reform (FORCLIME 2015).

Evaluations indicate that FMUs are still in an early phase and have so far not fulfilled their promise. Slow progress thus far is explained by a range of factors: a complex and dynamic policy environment, lack of clarity about legal roles and responsibilities, an insufficient budget, a lack of technical expertise and experienced staff members, a lack of integration within the broader institutional structure of forest administration, insufficient communication and trust-building between actors, and a lack of acknowledgement by other local actors. This analysis is more or less consistent across studies, including a 2015 nationwide survey of FMU leaders (Fisher et al. 2017); a 2011 survey of KPH officials (Bae et al. 2014); analyses of policy texts (Ngakan et al. 2008; E. Suwarno et al. 2015); a comparative analysis of forest governance in 11 districts in Central Kalimantan (A. Suwarno et al. 2015); case studies of FMUs in Lombok (Riggs et al. 2018), Riau (Suwarno et al. 2014) and Lampung (Ota 2015); and FORCLIME's own analysis of constraining factors (FORCLIME 2015). The revision of the decentralization law (UU 23/2014) is cited by FORCLIME as one of the sources of legal confusion (FORCLIME 2015). Sahide et al. (2016b) go a step further and argue that the 2014 revision is an extension of ongoing attempts towards recentralization, insofar as it will empower provincial governments to wrest control over FMUs from regency governments. 


\section{Conclusion}

If in the early 2000s it still seemed appropriate to describe decentralization as a 'big bang,' by now it is clear that Indonesia has, more accurately, embarked on a "dynamic process of decentralization and recentralization" which is "ever shifting the balance of power among the central, provincial and [regency] levels of government" (Myers et al. 2016, 11). Alternatively, in aspirational terms, it has been proposed that the promises of decentralization might be delivered "as a progressive, paradigmatic evolution" (Warman 2016, 23). That is to say, decentralization is not a singular event, but has over the last two decades unfolded in manifold processes and will continue to do so.

Several important characteristics of these processes emerge from this review. First of all, two of the main motivations for decentralization - democratization and territorial stability - have largely disappeared from the conversation about decentralization. What remains prominent is the search for effective forms of governance: improving service provision in remote areas, making government more responsive to the people it serves locally and improving natural resource management. Many of the revisions since 1999 ostensibly address flaws in the design of decentralization. These and other responses, then, to some degree reflect a necessary process of institutional learning and adaptation.

However, flaws of and obstacles to decentralization, as well as responses to them, also reflect a fight for power between different interest groups. Centering on the distribution of authority, benefits and accountability, this power struggle has exposed and exacerbated many legal ambiguities that hamper the attainment of effective governance. Actors in the center, reluctant to implement the decentralization laws, used the lack of legal detail to avoid having to follow the reformist spirit of the decentralization laws and were able to turn back some aspects of decentralization in the revised decentralization laws of 2004 and 2014. Regional elites, impatient with the slow development of a legal framework for decentralization, used those same legal ambiguities to move ahead with de facto decentralization. Based on the cursory program of the 1999 decentralization laws but spurred on by "the general euphoria for regional autonomy that spread across Indonesia in 1999 and 2000" (Barr et al. 2006b, 122), regency governments implemented local regulations and policies that preceded and exceeded the national legal basis for these actions.

The dynamic, inconclusive and contradictory nature of the different laws and processes pertaining to decentralization creates confusions and uncertainties for the different actors involved (Simarmata and Firdaus 2016). The regulatory framework changed over time, it took a long time for implementing regulations to follow through on laws and they were often of a different character than the laws they were supposed to implement, and the laws themselves shifted continually between decentralization and recentralization. Such volatile circumstances can induce opportunistic behavior and frustrate sustainable resource management (McCarthy 2004; Sloan et al. 2018). And, over time, decentralization has overturned New Order center-periphery relations, bringing back a political distribution of power over multiple centers by both revitalizing old regional centers and creating new ones (Haug et al. 2017c). These new power relations incited an unprecedented rate of administrative territorial splits and a great increase in the political salience of cultural identities.

Like decentralization more broadly, the devolution of power over forests to lower levels of government involves many complexities, ambiguities and reversals. There are many different laws, government regulations, ministerial decisions, and so on, which sometimes contradict each other. The tug-ofwar between the Ministry of Forestry and regency governments, combined with a lack of a wholeof-government approach to policy-making, has given rise to two parallel domains of law. Regency governments have been drawing on the decentralization laws and implementing regulations to claim more power over forests, while the Ministry of Forestry has been using the forestry laws and 
implementing regulations to maintain centralized control over forests. The Forest Management Units, whose development is moving at a swift pace, seem like a good example of the type of decentralization supported by both the Ministry of Forestry and international actors concerned about deforestation - local communities receive technical training and are paid to implement policies that are decided largely from above.

\section{Further research}

There has been much scholarly interest in the dramatic period of decentralization in Indonesia between 1999 and 2004. Now that the turbulence of fast-paced transition has settled down, it is time for an update. What is left now of the issues and dynamics that were identified for those early years, and what new issues have emerged? There is currently a lack of evidence on the effects of the 2014 revision of decentralization. Analyses of the text of the new law ${ }^{59}$ indicate that it recentralizes authority by introducing more regulations on the conduct of regional governments, reconceptualizing relationships between levels of government in terms of hierarchy rather than coordination, and transferring power from regency to provincial governments. But there is little evidence on how these adjustments play out. Have they provided the central oversight and institutional clarity necessary to allow for the development of effective local institutions, make decentralized governance more effective, and stop predatory, rent-seeking behavior by local elites? Or has the metaphorical pendulum swung back so far in the direction of central control that it feeds new regional discontent? Relatedly, does the empowerment of the provincial government level reinforce the regional identities that the 1999 decentralization laws successfully dispersed? And have new laws contributed to a stabilization of the forest margins, or merely added another layer of change and uncertainty?

Updated assessments of the cumulative effect of these decentralization processes over time would also be helpful. Understanding decentralization requires looking beyond the implications of specific laws and regulations, not least because "it is often not merely the new legislation but rather the ambiguity of the laws as well as unclear and overlapping authorities that provide local actors with the critical room to manoeuvre" (Haug et al. 2017b, 154). While much research has addressed the resulting politics of ethnic, religious and place-based identity, there is a lack of research on how decentralization interacts with "gendered and inter-generational inequalities" (Haug et al. 2017b, 158). Relatedly, there is still much to learn about the new hopes and aspirations (Long 2017), and new patterns of mobility (Bräuchler 2017), that changed center-periphery relations give rise to.

Research on the interplay between decentralization and forest management has focused on logging as a cause of deforestation, which was a subject of significant concern between 1999 and 2004. These days, however, more pressing matters relate to conversion to industrial plantations (notably oil palm), mining and forest fires. Decentralization affects the distribution of decision-making power and benefits regarding all of these issues. Studies suggest that controlling forest fires has become more difficult for central government as a result of relinquishing power to regional elites (e.g. Edwards and Heiduk 2015). On the other hand, effective governance of small-scale mining may require a more complete devolution of power to the regency level (Spiegel 2012). More empirical evidence is needed to assess these types of effects. 


\section{References}

Agrawal A and Ribot J. 1999. Accountability in decentralization: A framework with South Asian and West African cases. The Journal of Developing Areas 33:473-502.

Antlöv H. 2003a. Not enough politics! power, participation and the new democratic polity in Indonesia. In Aspinall E and Fealy G, eds. Local Power and Politics in Indonesia: Decentralisation \& Democratisation, Indonesia Update Series. Singapore: Institute of Southeast Asian Studies. 72-86.

Antlöv H. 2003b. Village government and rural development in Indonesia: The new democratic framework. Bulletin of Indonesian Economic Studies 39:193-214.

Antlöv H, Wetterberg A and Dharmawan L. 2016. Village governance, community life, and the 2014 Village Law in Indonesia. Bulletin of Indonesian Economic Studies 52:161-83.

Aragon LV. 2007. Elite competition in Central Sulawesi. In Schulte Nordholt H and van Klinken G, eds. Renegotiating Boundaries: Local Politics in Post-Suharto Indonesia. Boston and Leiden: Brill. 39-66.

Ardiansyah F and Jotzo F. 2013. Decentralization and avoiding deforestation. In Howes S and Rao MG, eds. Federal Reform Strategies: Lessons from Asia and Australia. Oxford: Oxford University Press. 273-302.

Arnold LL. 2008. Deforestation in decentralised Indonesia: What's law got to do with it? Environmental Law and Development Journal 4:75-100.

Aspinall E. 2014. Health care and democratization in Indonesia. Democratization 21:803-23.

Aspinall E. 2013. A nation in fragments. Critical Asian Studies 45:27-54.

Aspinall E. 2011. Democratization and ethnic politics in Indonesia: Nine theses. Journal of East Asian Studies 11:289-319.

Aspinall E. 2010. The irony of success. Journal of Democracy 21:20-34.

Aspinall E and Fealy G. 2003. Introduction: decentralization, democratization and the rise of the local. In Aspinall E and Fealy G, eds. Local Power and Politics in Indonesia: Decentralisation \& Democratisation, Indonesia Update Series. Singapore: Institute of Southeast Asian Studies. 1-12.

Bae JS, Kim Y-S, Fisher L, Moeliono M and DeShazo J. 2014. Promises and perils of decentralized forest governance: The case of Indonesia's Forest Management Units in Reducing Emission from Deforestation and Forest Degradation (REDD+). Society \& Natural Resources 27:1346-54.

Bappenas. 2015. Rencana Pembangunan Jangka Menengah Nasional [National Medium-Term Development Plans] 2015-2019. Jakarta: Bappenas

Barr CM, Resosudarmo IAP, McCarthy JF and Dermawan A. 2006a. Forests and decentralization in Indonesia: An overview. In Barr CM, Resosudarmo IAP, McCarthy JF and Dermawan A, eds. Decentralization of Forest Administration in Indonesia: Implications for Forest Sustainability, Economic Development, and Community Livelihoods. Bogor, Indonesia: Center for International Forestry Research. 1-17.

Barr CM, Resosudarmo IAP, McCarthy JF, Dermawan A, Moeliono M and Setiono B. 2006b. Decentralization and recentralization in Indonesia's forestry sector: Summary and recommendations. In Barr CM, Resosudarmo IAP, McCarthy JF and Dermawan A, eds. Decentralization of Forest Administration in Indonesia: Implications for Forest Sustainability, Economic Development, and Community Livelihoods. Bogor, Indonesia: Center for International Forestry Research. 121-133.

Bennett R. 2010. Decentralizing Authority After Suharto: Indonesia's Big Bang, 1998-2010, Innovations for Successful Societies. Princeton, New Jersey: Princeton University.

Booth A. 2014. Before the 'big bang': decentralization debates and practice in Indonesia, 1949-99. In Hill H, ed. Regional Dynamics in a Decentralized Indonesia, Indonesia Update Series. Singapore: Institute of Southeast Asian Studies. 25-44. 
Booth A. 2011. Splitting, splitting and splitting again: A brief history of the development of regional government in Indonesia since independence. Bijdragen tot de Taal-, Land-en Volkenkunde 167:31-59.

[Badan Pusat Statistik] BPS, [Badan Perencanaan Pembangunan Nasional] Bappenas, and [United Nations Development Programme Indonesia] UNDP Indonesia, 2004. The Economics of Democracy: Financing Human Development in Indonesia, Indonesia Human Development Report 2004. Jakarta: BPS, Bappenas and UNDP Indonesia.

Brata AG. 2008. Creating New Regions, Improving Regional Welfare Equality? Munich Personal RePEc Archive (MPRA) Paper No. 12540. Munich: University Library of Munich.

Bräuchler B. 2017. Changing patterns of mobility, citizenship and conflict in Indonesia. Social Identities 23:446-61.

Bräuchler B. 2015. The Cultural Dimension of Peace: Decentralization and Reconciliation in Indonesia, Rethinking Peace and Conflict Studies. Houndmills, Basingstoke, Hampshire: Palgrave Macmillan.

Bullinger C and Haug M. 2012. In and out of the forest: Decentralisation and recentralisation of forest governance in East Kalimantan, Indonesia. Austrian Journal of South-East Asian Studies $5: 243-62$.

Bunnell T. 2009. Human geographies of decentralized Indonesia. Indonesian Journal of Geography 41:189-200.

Bünte M. 2004. Dezentralisierung in Indonesien Teil 2: Bilanz und Perspektiven [Decentralization in Indonesia part 2: results and perspectives]. Journal of Current Southeast Asian Affairs 23:60-71.

Bünte M. 2003. Dezentralisierung in Indonesien Teil 1: Initiation und Inhalt [Decentralization in Indonesia part 1: initiation and content]. Journal of Current Southeast Asian Affairs 22:565-79.

Burgess R, Hansen M, Olken BA, Potapov P and Sieber S. 2012. The political economy of deforestation in the tropics. The Quarterly Journal of Economics 127:1707-54.

Butt S. 2010. Regional autonomy and legal disorder: the proliferation of local laws in Indonesia. Singapore Journal of Legal Studies 1:1-21.

Butt S and Parsons N. 2012. Reining in regional government - local taxes and investment in decentralised Indonesia. Sydney Law Review 34:91-106.

Casson A and Obidzinski K. 2002. From new order to regional autonomy: Shifting dynamics of "illegal" logging in Kalimantan, Indonesia. World Development 30:2133-51.

Colongon AA. 2003. What is happening on the ground? The progress of decentralisation. In Aspinall E and Fealy G, eds. Local Power and Politics in Indonesia: Decentralisation \& Democratisation, Indonesia Update Series. Singapore: Institute of Southeast Asian Studies. 87-101.

Crouch M. 2009. Religious regulations in Indonesia: Failing vulnerable groups? Review of Indonesian and Malaysian Affairs 43:53-103.

Dermawan A, Komarudin H and McGrath S. 2006. Decentralization in Indonesia's forestry sector: Is it over? What comes next? Presented at the 11th Biennial Global Conference of the International Association for the Study of Common Property (IASCP), Bali.

Duncan CR. 2007. Mixed outcomes: The impact of regional autonomy and decentralization on indigenous ethnic minorities in Indonesia. Development and Change 38:711-33.

Edwards SA and Heiduk F. 2015. Hazy days: Forest fires and the politics of environmental security in Indonesia. Journal of Current Southeast Asian Affairs 34:65-94.

Eilenberg M. 2017. Nested sovereignties: autonomy and authority in the Indonesian borderlands. In Haug M, Rössler M, Grumblies A-T and Ziegenhain P, eds. Rethinking Power Relations in Indonesia: Transforming the Margins. Routledge Contemporary Southeast Asia Series. London and New York: Routledge, Taylor \& Francis Group. 80-95.

Eindhoven M. 2007. New colonizers? Identity, representation and government in the post-New Order Mentawai Archipelago. In Schulte Nordholt H and van Klinken G, eds. Renegotiating Boundaries: Local Politics in Post-Suharto Indonesia. Boston and Leiden: Brill. 67-90.

Erb M and Sulistiyanto P, eds. 2009. Deepening Democracy in Indonesia? Direct Elections for Local Leaders (Pilkada). Singapore: Institute of Southeast Asian Studies. 
Fadliya and McLeod RH. 2010. Fiscal Transfers to Regional Governments in Indonesia (No. 2010-14), Departmental Working Papers. Canberra: The Australian National University, ArndtCorden Department of Economics.

Firman T. 2013. Territorial splits (Pemekaran Daerah) in decentralising Indonesia, 2000-2012: Local development drivers or hindrance? Space and Polity 17:180-96.

Fisher LA, Kim Y-S, Latifah S and Mukarom M. 2017. Managing forest conflicts: Perspectives of Indonesia's Forest Management Unit directors. Forest and Society 1:8.

Fisher MR, Moeliono M, Mulyana A, Yuliani EL, Adriadi A, Kamaluddin, Judda J and Sahide MAK. 2018. Assessing the new social forestry project in Indonesia: recognition, livelihood and conservation? International Forestry Review 20:346-61.

Fitrani F, Hofman B and Kaiser K. 2005. Unity in diversity? The creation of new local governments in a decentralising Indonesia. Bulletin of Indonesian Economic Studies 41:57-79.

FORCLIME. 2015. Development of Forest Management Units. Lessons Learned for Scaling Up. Bonn and Eschborn, Germany: Deutsche Gesellschaft für Internationale Zusammenarbeit (GIZ) GmbH.

Grumblies A-T. 2017. Conceptualising marginality in Indonesia. In Haug M, Rössler M, Grumblies A-T and Ziegenhain P, eds. Rethinking Power Relations in Indonesia: Transforming the Margins. London and New York: Routledge Contemporary Southeast Asia Series. Routledge, Taylor \& Francis Group. 81-113.

Hasan Z. 2011. Foreword, Minister of Forestry. In Forest Management Unit Development (FMU): Concept, Legislation, and Implementation. Jakarta: Ministry of Forestry, Directorate General of Forestry Planning, Directorate of Area Management and Preparation of Forest Area Utilisation. iii.

Haug M. 2017. Rich regency - prosperous people? Decentralisation, marginality and remoteness in East Kalimantan. In Haug M, Rössler M, Grumblies A-T and Ziegenhain P, eds. Rethinking Power Relations in Indonesia: Transforming the Margins. London and New York: Routledge Contemporary Southeast Asia Series. Routledge, Taylor \& Francis Group. 230-63.

Haug M, Rössler M and Grumblies A-T. 2017a. Introduction: contesting and reformulating centre periphery relations in Indonesia. In Haug M, Rössler M, Grumblies A-T and Ziegenhain P, eds. Rethinking Power Relations in Indonesia: Transforming the Margins. London and New York: Routledge Contemporary Southeast Asia Series. Routledge, Taylor \& Francis Group. 17-55.

Haug M, Rössler M and Grumblies A.-T. 2017b. Concluding Remarks. In Haug M, Rössler M, Grumblies A-T and Ziegenhain P, eds. Rethinking Power Relations in Indonesia: Transforming the Margins. London and New York: Routledge Contemporary Southeast Asia Series. Routledge, Taylor \& Francis Group. 150-59.

Haug M, Rössler M, Grumblies A-T and Ziegenhain P, eds. 2017c. Rethinking Power Relations in Indonesia: Transforming the Margins. London and New York: Routledge Contemporary Southeast Asia Series. Routledge, Taylor \& Francis Group.

Hill H, ed. 2014. An introduction to the issues. In Regional Dynamics in a Decentralized Indonesia, Indonesia Update Series. Singapore: Institute of Southeast Asian Studies. 1-22.

Hill H and Vidyattama Y. 2016. Regional development dynamics in Indonesia before and after the "big bang" decentralization. The Singapore Economic Review 61:1640027.

Hofman B and Kaiser K. 2004. The making of the 'big bang' and its aftermath: A political economy perspective. In Alm J, Martinez-Vazquez J and Indrawati SM, eds. Reforming Intergovernmental Fiscal Relations and the Rebuilding of Indonesia. Camberley, UK: Edward Elgar Publishing. $15-46$.

Holzhacker RL, Wittek R and Woltjer J, eds. 2016. Decentralization and Governance in Indonesia. Cham, Switzerland: Springer International Publishing.

Ilmma A and Wai-Poi M. 2014. Patterns of regional poverty in the new Indonesia. In Hill H, ed. Regional Dynamics in a Decentralized Indonesia, Indonesia Update Series. Singapore: Institute of Southeast Asian Studies. 98-132.

Jäger K. 2017. Redrawing borders and reshaping marginality in North Maluku. In Haug M, Rössler M, Grumblies A-T and Ziegenhain P, eds. Rethinking Power Relations in Indonesia: Transforming the Margins. London and New York: Routledge Contemporary Southeast Asia Series. Routledge, Taylor \& Francis Group. 170-202. 
Jaweng RE. 2014. Overcoming problems in new autonomy era. The Jakarta Post, 22/12/2014. Kartodihardjo H, Nugroho B and Putro HR. 2011. Forest Management Unit Development (FMU): Concept, Legislation, and Implementation. Jakarta: Ministry of Forestry, Directorate General of Forestry Planning, Directorate of Area Management and Preparation of Forest Area Utilisation.

Kim YS, Bae JS, Fisher LA, Latifah S, Afifi M, Lee SM and Kim I.-A. 2016. Indonesia's Forest Management Units: Effective intermediaries in REDD + implementation? Forest Policy and Economics 62: 69-77.

Kimura E. 2010. Proliferating provinces: Territorial politics in post-Suharto Indonesia. South East Asia Research 18:415-49.

Kimura, E. 2007. Marginality and Opportunity in the Periphery: The Emergence of Gorontalo Province in North Sulawesi. Indonesia 84: 71-95.

Larson AM. 2005. Democratic decentralization in the forestry sector: Lessons learned from Africa, Asia, and Latin America. In Colfer CJP and Capistrano D, eds. The Politics of Decentralization: Forests, Power, and People. London; Sterling, VA: Earthscan. 32-62.

Leer J. 2016. After the Big Bang: Estimating the effects of decentralization on educational outcomes in Indonesia through a difference-in-differences analysis. International Journal of Educational Development 49:80-90.

Lewis BD. 2017. Local government spending and service delivery in Indonesia: the perverse effects of substantial fiscal resources. Regional Studies 51:1695-707.

Lewis BD. 2014. Twelve years of fiscal decentralization: a balance sheet. In Hill H, ed. Regional Dynamics in a Decentralized Indonesia, Indonesia Update Series. Singapore: Institute of Southeast Asian Studies. 135-155.

Litvack J and Seddon J. 2000. Decentralization briefing notes. WBI Working Papers. Washington DC: The World Bank.

Long NJ. 2017. The edge of glory. Theorising centre-periphery relations in and from Indonesia's Riau Islands. In Haug M, Rössler M, Grumblies A-T and Ziegenhain P, eds. Rethinking Power Relations in Indonesia: Transforming the Margins. London and New York: Routledge Contemporary Southeast Asia Series. Routledge, Taylor \& Francis Group. 115-40.

Long NJ. 2013. Being Malay in Indonesia: histories, hopes and citizenship in the Riau Archipelago. Asian Studies Association of Australia Southeast Asia publications series. Honolulu, HI: University of Hawai'i Press ; Asian Studies Association of Australia.

Lund JF, Rutt RL and Ribot J. 2018. Trends in research on forestry decentralization policies. Current Opinion in Environmental Sustainability 32:17-22.

Malley MS. 2003. New rules, old structures and the limits of democratic decentralisation. In Aspinall E and Fealy G, eds. Local Power and Politics in Indonesia: Decentralisation \& Democratisation, Indonesia Update Series. Singapore: Institute of Southeast Asian Studies. 102-16.

McCarthy JF. 2005. Contesting decentralization: transnational policy narratives and the emergence of volatile socio-legal configurations in Central Kalimantan, Indonesia. In von Benda-Beckmann F, von Benda-Beckmann K and Griffiths AMO, eds. Mobile People, Mobile Law: Expanding Legal Relations in a Contracting World. London and New York: Routledge. 153-76.

McCarthy, JF. 2004. Changing to gray: decentralization and the emergence of volatile socio-legal configurations in Central Kalimantan, Indonesia. World Development 32:1199-223.

McGibbon R. 2004. Plural society in peril: migration, economic change, and the Papua conflict, Policy studies. Washington, DC: East-West Center Washington.

McWilliam A. 2011. Marginal governance in the time of Pemekaran: Case studies from Sulawesi and West Papua. Asian Journal of Social Science 39:150-70.

Mietzner M. 2014. Indonesia's decentralization: the rise of local identities and the survival of the nation-state. In Hill H, ed. Regional Dynamics in a Decentralized Indonesia, Indonesia Update Series. Singapore: Institute of Southeast Asian Studies. 45-67.

Moeliono M, Thuy PT, Waty Bong I, Wong GY and Brockhaus M. 2017. Social forestry - why and for whom? A comparison of policies in Vietnam and Indonesia. Forest and Society 1:1. 
Moeliono M, Wollenberg E and Limberg G, eds. 2009. The decentralization of forest governance: politics, economics and the fight for control of forests in Indonesian Borneo. London ; Sterling, VA: Earthscan.

[MoF] Ministry of Forestry. 2011. Legislation related to Forest Management Units (FMU). Jakarta: Ministry of Forestry, Directorate General of Forestry Planning.

Myers R, Intarini D, Sirait MT and Maryudi A. 2017. Claiming the forest: Inclusions and exclusions under Indonesia's 'new' forest policies on customary forests. Land Use Policy 66:205-13.

Myers R, Sanders AJP, Larson AM, Prasti RD and Ravikumar A. 2016. Analyzing multilevel governance in Indonesia: Lessons for REDD+ from the study of land use change in Central and West Kalimantan. CIFOR Working Paper no. 202. Bogor, Indonesia: Center for International Forestry Research (CIFOR).

Nasution A. 2016. The Government Decentralization Program in Indonesia. In Yoshino N and Morgan PJ, eds. Central and Local Government Relations in Asia: Achieving Fiscal Sustainability. ADBI Series on Asian Economic Integration and Cooperation. Rochester, NY: Social Science Research Network. 276-305.

Ngakan PO, Komarudin H and Moeliono M. 2008. Menerawang kesatuan pengelolaan hutan di era otonomi daerah. CIFOR Governance Brief No. 38. Bogor, Indonesia: Center for International Forestry Research (CIFOR).

Ostwald K, Tajima Y and Samphantharak K. 2016. Indonesia's decentralization experiment: motivations, successes, and unintended consequences. Journal of Southeast Asian Economies (JSEAE) 33:139-56.

Ota M. 2015. Can Forest Management Units improve the management of state forests in Indonesia's outer islands? Institutional analysis and case studies from Lampung Province of Sumatra. International Forestry Review 17:76-85.

Palmer C and Engel S. 2007. For better or for worse? Local impacts of the decentralization of Indonesia's forest sector. World Development 35:2131-49.

Pierskalla JH. 2016. Splitting the difference? The politics of district creation in Indonesia. Comparative Politics 48:249-68.

Quinn G. 2003. Coming apart and staying together at the centre: Debates over provincial status in Java and Madura. In Aspinall E and Fealy G, eds. Local Power and Politics in Indonesia: Decentralisation \& Democratisation, Indonesia Update Series. Singapore: Institute of Southeast Asian Studies. 164-78.

Rahmatunnisa M. 2015. Jalan Terjal Kebijakan Desentralisasi di Indonesia di Era Reformasi. PADJADJARAN Jurnal Ilmu Hukum (Journal of Law) 2:505-22.

Rasyid MR. 2004. The policy of decentralization in Indonesia. In Alm J, Martinez-Vazquez J and Indrawati SM, eds. Reforming Intergovernmental Fiscal Relations and the Rebuilding of Indonesia: The "Big Bang" Program and Its Economic Consequences, Studies in Fiscal Federalism and State-Local Finance. Cheltenham, UK ; Northampton, MA: Edward Elgar. 65-76.

Resosudarmo IAP. 2004. Closer to people and trees: Will decentralisation work for the people and the forests of Indonesia? European Journal of Development Research 16:110-32.

Resosudarmo IAP. 2003. Shifting power to the periphery: The impact of decentralisation on forests and forest people. In Aspinall E and Fealy G, eds. Local Power and Politics in Indonesia: Decentralisation \& Democratisation, Indonesia Update Series. Singapore: Institute of Southeast Asian Studies. 230-44.

Resosudarmo IAP, Oka NP, Mardiah S and Utomo NA. 2014. Governing fragile ecologies: a perspective on forest and land-based development in the regions. In Hill H, ed. Regional Dynamics in a Decentralized Indonesia, Indonesia Update Series. Singapore: Institute of Southeast Asian Studies. 260-84.

Ribot JC. 2002. African decentralization: local actors, powers and accountability. UNRISD Programme on Democracy, Governance and Human Rights Papers. No. 8. United Geneva: Nations Research Institute for Social Development. 
Riggs R, Langston J, Margules C, Boedhihartono A, Lim H, Sari D, Sururi Y, Sayer J, Riggs RA, Langston JD, et al.. 2018. Governance challenges in an Eastern Indonesian forest landscape. Sustainability 10:169.

Robinson K. 2011. Sawerigading vs. Sharia: Identities and political contestation in decentralised Indonesia. Asian Journal of Social Science 39:219-37.

Rohdewold R. 2003. Decentralisation and the Indonesian bureaucracy: Major changes, minor impact? In Aspinall E and Fealy G, eds. Local Power and Politics in Indonesia: Decentralisation \& Democratisation, Indonesia Update Series. Singapore: Institute of Southeast Asian Studies. 259-74.

Roth D. 2007. Many governors, no province; The struggle for a province in the Luwu-Tana Toraja area in South Sulawesi. In Schulte Nordholt H and van Klinken G, eds. Renegotiating Boundaries: Local Politics in Post-Suharto Indonesia. Boston and Leiden: Brill. 121-150.

Rudy, Hasyimzum Y, Heryandi and Khoiriah S. 2017. 18 years of decentralization experiment in Indonesia: Institutional and democratic evaluation. Journal of Politics and Law 10:132-39.

Sahide MAK, Maryudi A, Supratman S and Giessen L. 2016a. Is Indonesia utilising its international partners? The driving forces behind Forest Management Units. Forest Policy and Economics 69:11-20.

Sahide MAK, Supratman S, Maryudi A, Kim Y-S and Giessen L. 2016b. Decentralisation policy as recentralisation strategy: Forest Management Units and community forestry in Indonesia. International Forestry Review 18:78-95.

Sakai, M. 2009. Creating a new centre in the periphery of Indonesia: Sumatran Malay identity politics. In Sakai M, Banks G and Walker JH, eds. The Politics of the Periphery in Indonesia: Social and Geographical Perspectives. Singapore: NUS Press. 62-83.

Sayer J, Sunderland T, Ghazoul J, Pfund L, Sheil D, Meijaard E, Venter., Boedhihartono AK, Day M, Garcia C, et al. 2013. Ten principles for a landscape approach to reconciling agriculture, conservation, and other competing land uses. Proceedings of the National Academy of Sciences of the United States of America 110:8349-56.

Schulte Nordholt H and van Klinken G. 2007a. Introduction. In Schulte Nordholt H and van Klinken G, eds. Renegotiating Boundaries: Local Politics in Post-Suharto Indonesia. Boston and Leiden: Brill. 1-30.

Schulte Nordholt H and van Klinken G, eds. 2007b. Renegotiating Boundaries: Local Politics in PostSuharto Indonesia. Boston and Leiden: Brill.

Simarmata R and Firdaus AY. 2016. Pemberlakuan UU No. 23/2014 dan Desentralisasi di Bidang Pengelolaan Sumber Daya Alam. Jakarta: Perkumpulan untuk Pembaharuan Hukum Berbasis Masyarakat dan Ekologis (HuMa).

Skoufias E, Narayan A, Dasgupta B and Kaiser K. 2011. Electoral Accountability, Fiscal Decentralization and Service Delivery in Indonesia. World Bank Policy Research Working Paper No. 5641. Rochester, NY: Social Science Research Network.

Sloan S, Campbell MJ, Alamgir M, Collier-Baker E, Nowak MG, Usher G and Laurance WF. 2018. Infrastructure development and contested forest governance threaten the Leuser ecosystem, Indonesia. Land Use Policy 77:298-309.

Smith B. 2008. The origins of regional autonomy in Indonesia: experts and the marketing of political interests. Journal of East Asian Studies 8:211-34.

Soesastro H and Atje R. 2005. Survey of recent developments. Bulletin of Indonesian Economic Studies 41:5-34.

Spiegel SJ. 2012. Governance institutions, resource rights regimes, and the informal mining sector: regulatory complexities in Indonesia. World Development 40:189-205.

Steni B. 2016. Membedah UU Pemerintahan Daerah yang Baru. Jakarta: Institut Penelitian Inovasi Bumi (INOBU).

Sutiyo and Maharjan KL. 2017. Decentralization and Rural Development in Indonesia. Singapore: Springer. 
Suwarno A, Hein L and Sumarga E. 2015. Governance, decentralisation and deforestation: The case of Central Kalimantan Province, Indonesia. Quarterly Journal of International Agriculture 54:77100.

Suwarno E, Kartodihardjo H, Kolopaking LM and Soedomo S. 2015. The use of Ostrom's concept on rules-in-use in the analysis of regulation of Forest Management Unit formation. Jurnal Analisis Kebijakan Kehutanan 12:13-26.

Suwarno E, Kartodihardjo H, Kolopaking LM and Soedomo S. 2014. Institutional obstacles on the development of Forest Management Unit: The case of Indonesian Tasik Besar Serkap. American Journal of Environmental Protection 2:41-50.

Tomsa D. 2015. Toning down the 'big bang': the politics of decentralisation during the Yudhoyono years. In Aspinall E, Mietzner M and Tomsa D, eds. The Yudhoyono Presidency: Indonesia's Decade of Stability and Stagnation, Indonesia Update Series. Singapore: Institute of Southeast Asian Studies. 155-74.

van Klinken G. 2007. Communal Violence and Democratization in Indonesia: Small Town Wars, Routledge Contemporary Southeast Asia Series 15. London: Routledge.

Vel J. 2007. Campaigning for a new district in West Sumba. In Schulte Nordholt H and van Klinken G, eds. Renegotiating Boundaries: Local Politics in Post-Suharto Indonesia. Boston and Leiden: Brill. 91-120.

Vel JAC. 2008. Uma Politics; An Ethnography of Democratization in West Sumba, Indonesia, 19862006. Verhandelingen van het Koninklijk Instituut voor Taal-, Land- en Volkenkunde. Leiden and Boston: Brill.

Vel J, Zakaria Y and Bedner A. 2017. Law-making as a strategy for change: Indonesia's new Village Law. Asian Journal of Law and Society 4:447-71.

von Luebke C. 2009. The political economy of local governance: findings from an Indonesian field study. Bulletin of Indonesian Economic Studies 45:201-30.

Warman R. 2016. Decentralization and forestry in the Indonesian Archipelago: Beyond the Big Bang. South East Asia Research 24:23-40.

Wollenberg E, Moeliono M and Limberg G. 2009. Between state and society: Decentralization in Indonesia. In Moeliono M, Wollenberg E and Limberg, G, eds. The Decentralization of Forest Governance: Politics, Economics and the Fight for Control of Forests in Indonesian Borneo. London and Sterling, VA: Earthscan. 3-24.

Yasmi Y, Guernier J and Colfer CJ.. 2009. Positive and negative aspects of forestry conflict: lessons from a decentralized forest management in Indonesia. International Forestry Review 11:98-110.

Ziegenhain P. 2017. Decentralisation and its impact on the democratisation process. In Haug M, Rössler M, Grumblies A-T and Ziegenhain P, eds. Rethinking Power Relations in Indonesia: Transforming the Margins. London and New York: Routledge Contemporary Southeast Asia Series. Routledge, Taylor \& Francis Group. 57-80. 



\section{DOI: $10.17528 /$ cifor/007303}

CIFOR Working Papers contain preliminary or advance research results on tropical forest issues that need to be published in a timely manner to inform and promote discussion. This content has been internally reviewed but has not undergone external peer review.

The decentralization program that Indonesia embarked on in 1998 continues to unfold through manifold, sometimes contradictory processes. This working paper presents a concise and up-to-date overview of the aims, dimensions and dynamics of decentralization, with special attention to the decentralization of forestry. It demonstrates the dynamic, inconclusive and contradictory nature of the different decentralization laws and processes, and the resulting confusions, uncertainties and opportunities for the different actors involved. The paper further highlights a number of themes that merit further investigation. The result is intended to support the analysis of the Center for International Forestry Research (CIFOR)'s recent research data on the interface between migration and forestry in Malinau, North Kalimantan, and may also be useful to anyone interested in processes of decentralization in Indonesia or elsewhere. developing partners' capacity, and actively engaging in dialogue with all stakeholders to inform policies and practices that affect forests and people. CIFOR is a CGIAR Research Center, and leads the CGIAR Research Program on Forests, Trees and Agroforestry (FTA). Our headquarters are in Bogor, Indonesia, with offices in Nairobi, Kenya; Yaounde, Cameroon; Lima, Peru and Bonn, Germany. 